\title{
REVIEW
}

\section{Role of urea in microbial metabolism in aquatic systems: a biochemical and molecular review}

\author{
Caroline M. Solomon ${ }^{1, *}$, Jackie L. Collier ${ }^{2}$, Gry Mine Berg ${ }^{3}$, Patricia M. Glibert ${ }^{4}$ \\ ${ }^{1}$ Department of Biology, Gallaudet University, 800 Florida Avenue NE, Washington, DC 20002, USA \\ ${ }^{2}$ School of Marine and Atmospheric Sciences, Stony Brook University, Stony Brook, New York 11794-5000, USA \\ ${ }^{3}$ Department of Environmental Earth System Science, Stanford University, 397 Panama Mall, Stanford, California 94305, USA \\ ${ }^{4}$ University of Maryland Center for Environmental Science, Horn Point Laboratory, PO Box 775, Cambridge, \\ Maryland 21613, USA
}

\begin{abstract}
Urea synthesized commercially and formed naturally as a by-product of cellular metabolism is an important source of nitrogen (N) for primary producers in aquatic ecosystems. Although urea is usually present at ambient concentrations below $1 \mu \mathrm{M}-\mathrm{N}$, it can contribute $50 \%$ or more of the total $\mathrm{N}$ used by planktonic communities. Urea may be produced intracellularly via purine catabolism and/or the urea cycle. In many bacteria and eukaryotes, urea in the cell can be broken down by urease into $\mathrm{NH}_{4}{ }^{+}$and $\mathrm{CO}_{2}$. In addition, some bacteria and eukaryotes use urea amidolyase (UALase) to decompose urea. The regulation of urea uptake appears to differ from the regulation of urease activity, and newly available genomic sequence data reveal that urea transporters in eukaryotic phytoplankton are distinct from those present in Cyanobacteria and heterotrophic bacteria with different energy sources and possibly different enzyme kinetics. The diverse metabolic pathways of urea transport, production, and decomposition may contribute to differences in the role that urea plays in the physiology and ecology of different species, and in the role that each species plays in the biogeochemistry of urea. This review summarizes what is known about urea sources and availability, use of urea as an organic $\mathrm{N}$ growth source, rates of urea uptake, enzymes involved in urea metabolism (i.e. urea transporters, urease, UALase), and the biochemical and molecular regulation of urea transport and metabolic enzymes, with an emphasis on the potential for genomic sequence data to continue to provide important new insights.
\end{abstract}

KEY WORDS: Urea · Urea transport · Urease $\cdot$ Urea amidolyase $\cdot$ Urea cycle $\cdot$ Purine catabolism Resale or republication not permitted without written consent of the publisher

\section{INTRODUCTION}

The importance of urea, and other regenerated forms of nitrogen $(\mathrm{N})$, in phytoplankton production and its inclusion in estimates of regenerated production has long been recognized (sensu Dugdale \& Goering 1967); however, there were few available data on urea uptake by phytoplankton until the 1970s (McCarthy 1972). Although urea is usually present at ambient concentrations below $1 \mu \mathrm{M}-\mathrm{N}$ in aquatic ecosystems, it is an important source of regenerated $\mathrm{N}$ and a major substrate for phytoplankton nutrition (e.g. Antia et al.
1991, Berman \& Bronk 2003). The natural role of urea in coastal ecosystems is now being strongly affected by anthropogenic enrichment of urea, which appears to be associated with increasing occurrences of some harmful algal blooms (HABs; Glibert et al. 2006). Thus, gaining a better understanding of urea sources, sinks, and dynamics is an important goal in aquatic microbial ecology. This review supports that effort by integrating the current state of knowledge on biochemical processes and regulation with newer information from recent genomic sequencing projects. Specifically, this review covers urea sources and availability, use of urea 
as an organic $\mathrm{N}$ growth source, rates of urea uptake and enzymatic activity in urea metabolism (i.e. urease, UALase), and the biochemical and molecular regulation of urea transport. Much research is needed to more fully understand the links between the biochemistry of urea and its importance in the ecology of aquatic systems.

\section{UREA SOURCES, AVAILABILITY, AND RATES OF UPTAKE AND GROWTH}

\section{Sources of urea to aquatic ecosystems}

Urea in aquatic ecosystems comes from both natural and anthropogenic sources. Among the natural sources of urea in the water column are regeneration by heterotrophic bacteria (Mitamura \& Saijo 1981, Cho \& Azam 1995, Cho et al. 1996, Berg \& Jørgensen 2006), excretion by macro- and microzooplankton (Corner \& Newell 1967, Mayzaud 1973, Bidigare 1983, Miller \& Glibert 1998, L'Helguen et al. 2005, Miller \& Roman 2008, Painter et al. 2008), and release by phytoplankton (Hansell \& Goering 1989, Bronk et al. 1998, Bronk 2002). Urea is also produced by benthic heterotrophic bacteria and macrofauna and released from sediments into the water column (Lomstein et al. 1989, Lund \& Blackburn 1989, Pedersen et al. 1993, Therkildsen et al. 1997). The supply of regenerated urea may vary daily as copepods such as Acartia tonsa excrete more urea during night-time hours (Miller \& Glibert 1998, Miller \& Roman 2008). Urea regeneration rates under some conditions may exceed rates of $\mathrm{NH}_{4}{ }^{+}$regeneration (e.g. Chesapeake Bay; Bronk et al. 1998). It has also been shown that macrofauna such as sharks (McCarthy \& Kamykowski 1972), aggregations of larval fish (McCarthy \& Whitledge 1972), and seabird guano can be sources of urea on local scales (Harrison et al. 1985). Urea also enters aquatic ecosystems via atmospheric deposition (Timperley et al. 1985, Cornell et al. 1995, Peierls \& Paerl 1997, Mace et al. 2003) and in this form may come from both natural and anthropogenic sources.

In addition to the many natural sources, anthropogenic urea that enters aquatic ecosystems is produced commercially via the Wöhler process in which silver cyanate and ammonia are combined (Smil 2001). Serendipitously discovered in 1828, this chemical synthesis of urea has led to industrial production that now nears 70 million metric tons $\mathrm{yr}^{-1}$ (Berman \& Bronk 2003, Glibert et al. 2006). Worldwide use of urea has increased more than 100-fold in the past 4 decades (Glibert et al. 2006). Of its commercial use, the dominant application is as a fertilizer. Urea is also used as a feed additive, in herbicides and pesticides, as a deicer for airplanes, and in bioremediation (Glibert et al. 2006).

\section{Urea availability in aquatic ecosystems}

Urea concentrations in aquatic ecosystems are variable, ranging from nondetectable (less than $\sim 0.05 \mu \mathrm{M}$ $\mathrm{N})$ to tens of $\mu \mathrm{M}-\mathrm{N}$ measured using standard colorimetric techniques (e.g. McCarthy 1970, Holmes et al. 1999, Revilla et al. 2005). The fact that each molecule of urea contains $2 \mathrm{~N}$ atoms has contributed to some confusion in the literature with respect to units and concentrations. Some authors refer to concentrations of 'urea' while others refer to concentrations of ' $\mathrm{N}$ ', and in many cases the authors do not clearly specify which unit was used. The resulting 2 -fold uncertainty can sometimes make comparisons difficult. Units of ' $\mathrm{N}$ ' are used herein.

Oceanic concentrations of urea are typically very low, and often nanomolar-N concentrations are measured (Bronk 2002, Painter et al. 2008). In contrast, concentrations of urea in coastal, estuarine, and riverine systems are quite variable, and concentrations as high as 25 to $50 \mu \mathrm{M}-\mathrm{N}$ have been reported in tributaries of the Chesapeake Bay (Lomas et al. 2002, Glibert et al. 2005), nearshore waters adjacent to the heavily fertilized Yaqui Valley, Mexico (Glibert et al. 2006), Santa Cruz, California (Kudela et al. 2008), and the Knysna Estuary, South Africa (Switzer 2008). Freshwater concentrations of urea are similar to those in coastal ecosystems and are quite variable. Urea concentrations vary from undetectable to 6-11 $\mu \mathrm{M}-\mathrm{N}$ in Lake Kinneret, Israel (Berman 1974), 0.24-1.17 $\mu \mathrm{M}-\mathrm{N}$ in Lake Biwa (Mitamura \& Saijo 1981), and 0.02$50 \mu \mathrm{M}-\mathrm{N}$ in Polish lakes (Siuda \& Chróst 2006). Urea concentrations are higher in mesotrophic than eutrophic Polish lakes (Siuda \& Chróst 2006). In general, urea concentrations in aquatic ecosystems are less than those of $\mathrm{NO}_{3}{ }^{-}$and $\mathrm{NH}_{4}{ }^{+}$, but may exceed the concentrations of these inorganic $\mathrm{N}$ forms on occasion, and for short periods of time, particularly when runoff occurs from heavily fertilized areas (Glibert et al. 2001, 2006, Kudela et al. 2008, Switzer 2008).

\section{Rates of urea uptake}

Despite the fact that urea is often present in lower concentrations than $\mathrm{NO}_{3}{ }^{-}$and $\mathrm{NH}_{4}{ }^{+}$, in coastal and oceanic ecosystems, rates of urea uptake can be greater than rates of inorganic $\mathrm{N}$ uptake and can account for more than $50 \%$ of $\mathrm{N}$ uptake by planktonic communities (McCarthy 1972, Kaufman et al. 1983, Glibert et al. 1991, Berg et al. 1997, Bronk et al. 1998, Kudela \& Cochlan 2000, Berman \& Bronk 2003). Urea uptake rates in aquatic systems range from <0.1 nM-N $\mathrm{h}^{-1}$ to $3.6 \mu \mathrm{M}-\mathrm{N} \mathrm{h}^{-1}$ (Kristiansen 1983, Berg et al. 1997, Lomas et al. 2002, Berman \& Bronk 2003). Sometimes, 
rates of urea uptake can meet most of the phytoplankton demand for N. For example, urea has been observed to support a large fraction of the $\mathrm{N}$ demand of many HABs including the dinoflagellate Lingulodinium polyedrum off the coast of Mexico (Kudela \& Cochlan 2000), the dinoflagellate Alexandrium catenella in Thau Lagoon in Southern France (Collos et al. 2004), and the pelagophyte Aureococcus anophagefferens in Great South Bay and Peconic Bay, New York (Lomas et al. 1996, Berg et al. 1997, Gobler et al. 2002).

Heterotrophic bacteria can be both producers and consumers of urea, and their contribution to urea uptake relative to that of phytoplankton is often difficult to assess (Jørgensen 2006). Uptake of urea can account for a small $(<3 \%)$ to large $(41 \%)$ part of total bacterial N uptake (Wheeler \& Kirchman 1986, Kirchman et al. 1991, Jørgensen et al. 1999a, Jørgensen 2006). The percentage contribution of bacteria to total plankton community urea uptake also varies from small $(<10 \%$; Cho \& Azam 1995, Cho et al. 1996) to large (>80\%; Middelburg \& Nieuwenhuize 2000). The variability in contribution by bacteria to total microbial urea uptake may reflect variability in their roles in an ecosystem. For example, in a transect in the Gulf of Riga, bacteria produced $53 \%$ of the urea near the shore and progressively became consumers offshore where they utilized $20 \%$ of the urea (Jørgensen et al. 1999b).

\section{Phytoplankton rates of growth on urea as sole $\mathbf{N}$ source}

Some field observations have suggested that urea may promote the growth of particular phytoplankton over others (e.g. flagellate species over diatoms; Antia et al. 1991, Glibert \& Terlizzi 1999, Berg et al. 2003). Many algal species have been found to grow well on urea, and for most species surveyed there appears to be little difference in growth rate for cells grown under comparable environmental conditions using $\mathrm{NO}_{3}{ }^{-}, \mathrm{NH}_{4}{ }^{+}$, or urea as the sole growth source of $\mathrm{N}$ (Table 1), although Berman \& Chava (1999) reported much higher rates on urea than $\mathrm{NO}_{3}{ }^{-}$and $\mathrm{NH}_{4}{ }^{+}$for 3 Cyanobacteria, a diatom, and a chlorophyte. For some species, such as Emiliania huxleyi (Pustizzi et al. 2004, Strom \& Bright 2009) and Aureococcus anophagefferens (Berg et al. 2008), there appear to be differences among clones in their rate of growth on urea. In some cases, growth was faster on urea than $\mathrm{NO}_{3}{ }^{-}$and $\mathrm{NH}_{4}{ }^{+}$ at a lower irradiance; this pattern could be seen for Chaetoceros gracilis, Dunaliella tertiolecta, and Heterosigma akashiwo (Levasseur et al. 1993, Herndon \& Cochlan 2007; Table 1). The wide range of growth conditions used by different investigators prevents further comparisons of growth of different species on urea.
The phytoplankton included in Table 1 can all grow well on urea, but some species cannot. Previous investigators have noted that some diatoms cannot use urea as a source of $\mathrm{N}$ for growth (Neilson \& Larsson 1980). More recently, Hildebrand \& Dahlin (2000) reported complete growth arrest of the diatom Cylindrotheca fusiformis when its sole $\mathrm{N}$ source was switched from $\mathrm{NO}_{3}{ }^{-}$to urea and its $\mathrm{NO}_{3}^{-}$transporter was concomitantly up-regulated to the same level as in N-starved cultures. Some phytoplankton may not grow on urea, because they do not possess enzymes essential for urea uptake and/or catabolism. The genes encoding the enzyme urease were shown to be essential for the marine cyanobacterium Synechococcus strain WH7805 to grow on urea, while a Synechococcus strain that could not grow on urea (WH7803) lacked the enzyme urease (Collier et al. 1999). Some strains of Prochlorococcus do not contain the urease gene in their genomes (e.g. strains MIT9211, MIT8515, CCMP1375), but no physiological data are available to determine if these strains cannot grow on urea. There is apparently a great deal of variation in the use of urea relative to other N sources, with some phytoplankton growing best on urea, others growing better on other $\mathrm{N}$ sources, and still others unable to utilize urea at all. Additional work is needed to better describe urea utilization by more different phytoplankton taxa, and to understand the molecular genetic bases for differences among them.

A comparable body of literature on the growth of heterotrophic bacterial species is needed to understand their importance in aquatic ecosystems when using urea and other forms of N. Research in this area would complement our understanding of phytoplankton $\mathrm{N}$ nutrition and assist in the interpretation of field data.

\section{UREA METABOLISM IN BACTERIA AND PHYTOPLANKTON}

\section{Molecular mechanisms of urea transport}

Because ambient concentrations are generally low, urea mostly enters a microbial cell from external sources by active transport (Fig. 1). Urea active transporters have been identified in a number of bacteria and phytoplankton. In several prokaryotes, including the actinobacterium Corynebacterium glutamicum and Cyanobacteria, urea uptake occurs via ABC-type (ATP-binding cassette) transporters that use energy from ATP to transport urea across the cell membrane and are encoded by the urtABCDE operon (Beckers et al. 2004, Su et al. 2005; Table 2). Energy-dependent urea transporters have been described in several other heterotrophic bacterial species, including Deleya (now Halomonas) venusta HG1, Pseudomonas aeruginosa, 
Table 1. Estimates of growth rate $(\mu)$ from studies in which a unialgal culture was grown using $\mathrm{NO}_{3}{ }^{-}, \mathrm{NH}_{4}{ }^{+}$, or $\mathrm{urea}$ as the sole $\mathrm{N}$ substrate. Where standard deviations (SD) are not given, they either were not reported in the original report or were difficult to accurately extract from the reported graph

\begin{tabular}{|c|c|c|c|c|c|c|c|c|}
\hline Species & $\begin{array}{l}\text { Light level }(\mu \mathrm{mol} \\
\left.\text { photons } \mathrm{m}^{-2} \mathrm{~s}^{-1}\right)\end{array}$ & \multicolumn{2}{|c|}{$\begin{array}{c}\mathrm{NO}_{3}^{-} \\
\mu\left(\mathrm{d}^{-1}\right) \pm \mathrm{SD}\end{array}$} & $\mu \stackrel{\mathrm{NH}}{\mu\left(\mathrm{d}^{-1}\right)}$ & $\mathrm{I}^{+}{ }^{+} \mathrm{SD}$ & \multicolumn{2}{|c|}{ Urea } & Source \\
\hline \multicolumn{9}{|l|}{ PHOTOSYNTHETIC BACTERIA } \\
\hline \multicolumn{9}{|l|}{ Cyanophytes } \\
\hline Synechococcus sp. ${ }^{a}$ & 80 & 0.4 & & 1.3 & & 2.3 & & Berman \& Chava (1999) \\
\hline Microcystis aeruginosa $^{\mathrm{a}}$ & 80 & 0.6 & & 0.8 & & 2.5 & & Berman \& Chava (1999) \\
\hline Microcystis aeruginosa & & 0.34 & & 0.31 & & 0.41 & & C. M. Solomon (unpubl.) \\
\hline Aphanizomenon ovalisporum ${ }^{\mathrm{a}}$ & 80 & 0.6 & & 0.4 & & 1.3 & & Berman \& Chava (1999) \\
\hline \multicolumn{9}{|l|}{ RED LINEAGE } \\
\hline \multicolumn{9}{|l|}{ Diatoms } \\
\hline Thalassiosira pseudonana ${ }^{\mathrm{a}}$ & $\mathrm{b}$ & 3.6 & & 3.6 & & 3.2 & & Ferguson et al. (1976) \\
\hline Chaetoceros gracilis & 170 & 1.84 & 0.02 & 1.56 & 0.10 & 1.28 & 0.06 & Levasseur et al. (1993) \\
\hline Chaetoceros gracilis & 7 & 0.43 & 0.01 & 0.39 & 0.11 & 0.49 & 0.05 & Levasseur et al. (1993) \\
\hline Cyclotella sp. ${ }^{\mathrm{a}}$ & 80 & 3.0 & & 2.8 & & 4.3 & & Berman \& Chava (1999) \\
\hline Pseudo-nitzschia multiseries, $P n-1^{\mathrm{c}}$ & $150-20$ & 0.75 & 0.1 & 0.75 & 0.18 & 0.3 & 0.1 & Thessen et al. (2009) \\
\hline Pseudo-nitzschia fraudulent, $P n 10^{\mathrm{c}}$ & $150-200$ & 0.82 & 0.05 & 0.85 & 0.07 & 0.58 & 0.08 & Thessen et al. (2009) \\
\hline Pseudo-nitzschia callianth, $P n-13^{\mathrm{c}}$ & $150-200$ & 0.72 & 0.07 & 0.7 & 0.07 & 0.44 & 0.02 & Thessen et al. (2009) \\
\hline \multicolumn{9}{|l|}{ Dinoflagellates } \\
\hline Gymnodinium sanguineum & 170 & 0.41 & 0.01 & 0.43 & 0.01 & 0.18 & 0.03 & Levasseur et al. (1993) \\
\hline Gymnodinium sanguineum & 7 & 0.17 & 0.02 & 0.14 & 0.02 & 0.1 & 0.02 & Levasseur et al. (1993) \\
\hline Karenia brevis strain C6 & 30 & 0.08 & 0.01 & 0.10 & 0.0 & 0.10 & 0.01 & Sinclair et al. (2009) \\
\hline Karenia brevis strain $C 3$ & 30 & 0.09 & 0.01 & 0.10 & 0.01 & 0.10 & 0.01 & Sinclair et al. (2009) \\
\hline Karenia brevis strain CCMP 299 & 30 & 0.08 & 0.02 & 0.09 & 0.03 & 0.12 & 0.03 & Sinclair et al. (2009) \\
\hline Prorocentrum minimum & 300 & 0.34 & 0.02 & 0.31 & 0.04 & 0.29 & 0.01 & Solomon \& Glibert (2008) \\
\hline Karlodinium veneficum & 300 & 0.42 & 0.06 & 0.52 & 0.06 & 0.49 & 0.07 & Solomon \& Glibert (2008) \\
\hline Heterocapsa triquetra & 300 & 0.21 & 0.04 & 0.24 & 0.0 & 0.23 & 0.01 & Solomon \& Glibert (2008) \\
\hline \multicolumn{9}{|l|}{ Cryptophytes } \\
\hline Storeatula major & 300 & 0.65 & 0.02 & 0.71 & 0.03 & 0.69 & 0.02 & Solomon \& Glibert (2008) \\
\hline \multicolumn{9}{|l|}{ Haptophytes } \\
\hline Isochrysis sp. & 300 & 0.85 & 0.01 & 0.72 & 0.01 & 0.78 & 0.0 & Solomon \& Glibert (2008) \\
\hline Emiliania huxleyi strain 370 & $45-60$ & 0.13 & $<0.01$ & 0.15 & $<0.01$ & 0.19 & $<0.01$ & Strom \& Bright (2009) \\
\hline Emiliania huxleyi strain $374 \exp 1$ & $45-60$ & 0.21 & $<0.01$ & 0.23 & 0.01 & 0.33 & 0.01 & Strom \& Bright (2009) \\
\hline Emiliania huxleyi strain $373 \exp 1$ & $45-60$ & 0.10 & $<0.01$ & 0.05 & 0.02 & 0.09 & $<0.01$ & Strom \& Bright (2009) \\
\hline Emiliania huxleyi strain 379 & $45-60$ & 0.18 & 0.01 & 0.15 & 0.02 & 0.07 & $<0.01$ & Strom \& Bright (2009) \\
\hline \multicolumn{9}{|l|}{ Raphidophytes } \\
\hline Heterosigma akashiwo $^{\mathrm{d}}$ & 110 & 0.82 & $\sim 0.02$ & 0.89 & $\sim 0.02$ & 0.82 & $\sim 0.03$ & Herndon \& Cochlan (2007) \\
\hline Heterosigma akashiwo $^{\mathrm{d}}$ & 40 & 0.46 & $\sim 0.08$ & 0.57 & $\sim 0.08$ & 0.61 & $\sim 0.08$ & Herndon \& Cochlan (2007) \\
\hline \multicolumn{9}{|l|}{ Pelagophytes } \\
\hline Aureococcus anophagefferens & 400 & 0.55 & 0.03 & nd & & 0.59 & 0.02 & Pustizzi et al. (2004) \\
\hline Aureococcus anophagefferens & 100 & 0.45 & & nd & & 0.45 & & Pustizzi et al. (2004) \\
\hline Aureococcus anophagefferens & 50 & 0.51 & & 0.48 & & 0.59 & & Berg et al. (2008) \\
\hline Aureoumbra lagunensis ${ }^{\mathrm{d}}$ & 220 & 0.31 & $<0.01$ & 0.68 & 0.04 & 0.55 & 0.03 & Muhlstein \& Villareal (2007) \\
\hline Aureoumbra lagunensis ${ }^{\mathrm{d}}$ & 140 & 0.26 & $<0.01$ & 0.62 & 0.04 & 0.48 & 0.03 & Muhlstein \& Villareal (2007) \\
\hline Aureoumbra lagunensis ${ }^{\mathrm{d}}$ & 55 & 0.21 & $<0.01$ & 0.41 & 0.03 & 0.45 & 0.02 & Muhlstein \& Villareal (2007) \\
\hline \multicolumn{9}{|l|}{ GREEN LINEAGE } \\
\hline \multicolumn{9}{|l|}{ Chlorophytes } \\
\hline Dunaliella tertiolecta & 170 & 1.41 & 0.09 & 1.42 & 0.04 & 1.33 & 0.06 & Levasseur et al. (1993) \\
\hline Dunaliella tertiolecta & 7 & 0.25 & 0.01 & 0.27 & 0.02 & 0.3 & 0.02 & Levasseur et al. (1993) \\
\hline Pediastrum duplex ${ }^{\mathrm{a}}$ & 80 & 0.9 & & 0.7 & & 1.8 & & Berman \& Chava (1999) \\
\hline $\begin{array}{l}{ }^{\mathrm{a}} \text { Growth rates were estimated from } \\
\mathrm{b} \text { Paper reported a light level of } 5.4 \mathrm{k} \\
{ }^{\mathrm{b}} \text { This paper reports on the effect of } \\
\text { given here }\end{array}$ & $\begin{array}{l}\text { plotted changes d } \\
\text { klux for which no } \\
\text { N source for } 9 \text { stra }\end{array}$ & $\begin{array}{l}\text { luring ex } \\
\text { conversi } \\
\text { ins of } P s\end{array}$ & $\begin{array}{l}\text { xponen } \\
\text { ion is a } \\
\text { seudo-1 }\end{array}$ & $\begin{array}{l}\text { Ial growt } \\
\text { ailable to } \\
\text { itzschia; }\end{array}$ & $\begin{array}{l}\text { th } \\
\text { o } \mu \text { mol } \\
\text { only th }\end{array}$ & $\begin{array}{l}\text { hotons } n \\
\text { first clor }\end{array}$ & $\begin{array}{l}{ }^{-2} s^{-1} \\
\text { he for ec }\end{array}$ & h Pseudo-nitzschia species is \\
\hline${ }^{\mathrm{d}}$ Error bars estimated from publicati & & & & & & & & \\
\hline
\end{tabular}




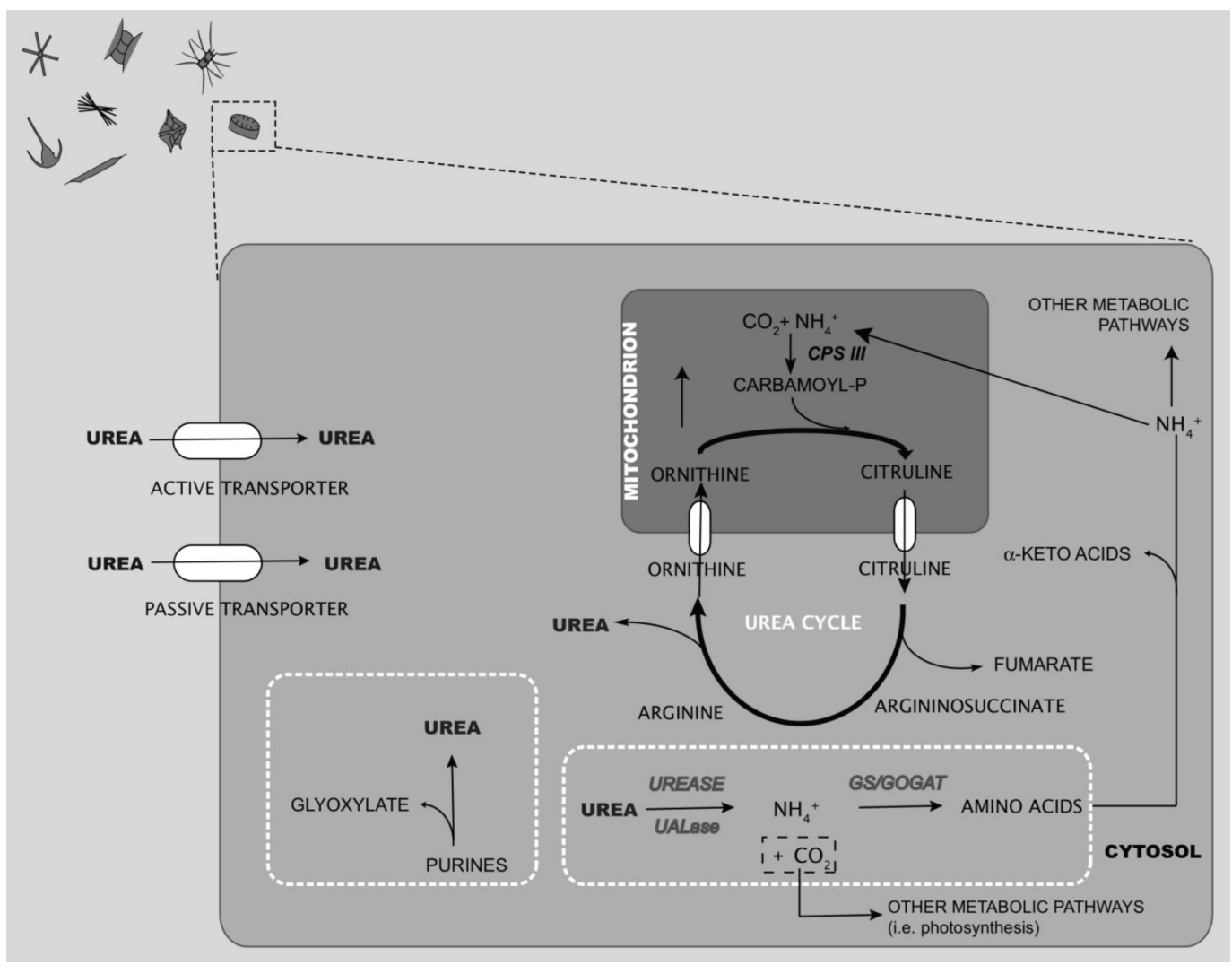

Fig. 1. Urea metabolism pathways. CPS III: carbamoylphosphate synthetase; GS/GOGAT: glutamine synthetase/glutamine: 2-oxoglutarate amidotransferase; UALase: urea amidolyase

and Bacillus megaterium (Jahns et al. 1988, Jahns \& Kaltwasser 1989, Jahns 1992a,b), and genomic sequence data suggest that at least for $P$. aeruginosa the transporter is a urt homologue.

Genomic sequencing has revealed that marine unicellular photosynthetic eukaryotes possess the gene DUR3 (Table 2), which encodes a high-affinity urea active transporter that is part of the larger sodium: solute symporter family (SSSF) of transport proteins (Wang et al. 2008). SSSF porters use the energy from a sodium gradient across the cell membrane to transport the solute into the cell (Jung 2002) and are also present in higher plants, mosses, and fungi (Wang et al. 2008). The DUR genes were initially identified as part of the allantoin catabolic pathway in yeast (Genbauffe \& Cooper 1986) and also include the DUR1 and DUR2 genes which encode the urea carboxylase and allophanate hydrolase enzymes, respectively, discussed in further detail below. Of the phytoplankton DUR3 transporters surveyed here, the red algal lineage DUR3 amino acid sequences from the pelagophyte Aureococcus anophagefferens, the dinoflagellate Heterocapsa triquetra, and the diatoms Thalassiosira pseudonana and Phaeodactylum tricornutum group together. However, the DUR3 sequences of the haptophyte Emiliania huxleyi, also of the red algal lineage, were highly divergent (Fig. 2). The green algal lineage phytoplankton Ostreococcus sp. DUR3 clustered with the higher plants and the main red algal lineage group, while the freshwater Chlamydomonas reinhardtii DUR3 sequences were more divergent. A. anophagefferens has one full-length DUR3 gene and one truncated DUR3 gene sequence in its genome (protein IDs 71789 and 6161, respectively), whereas $C$. reinhardtii has 3 closely related DUR3 genes. The diatom $P$. tricornutum has 2 DUR3 genes, whereas T. pseudonana has one DUR3 gene. A literature review of urea uptake kinetics in phytoplankton cultures revealed that the maximum rate of uptake $\left(\mathrm{V}_{\max }\right)$ may be higher in the red algal lineage phytoplankton, while affinity for urea $\left(\mathrm{K}_{\mathrm{s}}\right)$ may be higher in the green lineage phytoplankton, suggesting a difference in enzyme kinetics for the different branches of the DUR3 gene family (Table 3).

In addition to the high-affinity transporter DUR3, the movement of urea across cell membranes can be facilitated by families of proteins including (1) the urea/ amide channels, (2) the major intrinsic proteins (MIPs), also known as water channels or aquaporins (AQPs), and (3) low-affinity urea transporters of the solute carrier family 14, homologous to mammalian kidney urea 
Table 2. Urea metabolism genes in phytoplankton. A select number of freshwater and marine Cyanobacteria, chosen on the basis of prevalence in aquatic ecosystems, are represented in the table. Presence of genes in Cyanobacteria was determined by running BLAST searches to known genes at CyanoBase (http://genome.kazusa.or.jp/cyanobase/). Presence of genes in completely sequenced eukaryotic phytoplankton was determined first by doing searches in the Joint Genome Institute (JGI) database

\begin{tabular}{|c|c|c|c|}
\hline \multirow[b]{2}{*}{ Phytoplankton species } & \multirow[b]{2}{*}{$\begin{array}{l}\text { Urea } \\
\text { transporter }\end{array}$} & \multirow{2}{*}{ Urease } & \multirow{2}{*}{$\begin{array}{c}\text { Urea amidolyase } \\
\text { (both urea carboxy- } \\
\text { lase and allophanate } \\
\text { hydrolase) }\end{array}$} \\
\hline & & & \\
\hline Protein domains & $\begin{array}{c}\text { URT }=\text { IPR003439 } \\
\text { DUR3 = IPR001734 } \\
\text { SLC14A = IPR004937 }\end{array}$ & $\begin{array}{l}\text { IPR005848 } \\
\text { (ureC, } \alpha \\
\text { subunit) }\end{array}$ & $\begin{array}{l}\text { IPR005482 } \\
\text { IPR000120 }\end{array}$ \\
\hline \multicolumn{4}{|l|}{$\begin{array}{l}\text { PHOTOSYNTHETIC BACTERIA } \\
\text { Cyanophytes }\end{array}$} \\
\hline Synechocystis sp. PCC 6803 & $\begin{array}{c}\text { URT } \\
\left(N P_{-} 442328\right)\end{array}$ & $\begin{array}{c}\text { URE } \\
\left(N P_{-} 440403\right)\end{array}$ & \\
\hline Synechococcus sp. WH8102 & $\begin{array}{c}\text { URT } \\
\left(N P \_898527\right)\end{array}$ & $\begin{array}{c}\text { URE } \\
\left(N P \_898538\right)\end{array}$ & \\
\hline $\begin{array}{l}\text { Nostoc sp. PCC } 7120 \\
\text { (formerly Anabaena sp. PCC } 7210 \text { ) }\end{array}$ & $\begin{array}{c}\text { URT } \\
\left(N P_{-} 485987\right)\end{array}$ & $\begin{array}{c}\text { URE } \\
\left(N P_{-} 487710\right)\end{array}$ & \\
\hline Microcystis aeruginosa NIES-843 & $\begin{array}{c}\text { URT } \\
\left(Y P_{-} 001655632\right)\end{array}$ & $\begin{array}{c}\text { URE } \\
\left(Y P_{-} 001661147\right)\end{array}$ & \\
\hline $\begin{array}{l}\text { Prochlorococcus marinus subsp. } \\
\text { pastoris str. CMP1986 (formerly } \\
\text { Prochlorococcus marinus MED4) }\end{array}$ & $\begin{array}{c}\text { URT } \\
\left(N P \_893091\right)\end{array}$ & $\begin{array}{c}\text { URE } \\
\left(N P \_893080\right)\end{array}$ & \\
\hline Cyanothece sp. ATCC 51142 & $\begin{array}{c}\text { URT } \\
\left(Y P_{-} 001805935\right)\end{array}$ & & \\
\hline $\begin{array}{l}\text { Trichodesmium erythraeum } \\
\text { IMS101 }\end{array}$ & $\begin{array}{c}\text { URT } \\
\left(Y P_{-} \text {720094) }\right.\end{array}$ & $\begin{array}{c}\text { URE } \\
\left(Y P_{-} 720654\right)\end{array}$ & \\
\hline \multicolumn{4}{|l|}{$\begin{array}{l}\text { RED LINEAGE } \\
\text { Diatoms }\end{array}$} \\
\hline $\begin{array}{l}\text { Thalassiosira pseudonana } \\
\text { (centric diatom }_{i} \\
\text { Armbrust et al. 2004) }\end{array}$ & $\begin{array}{c}\text { DUR3 } \\
\left(X P_{-} 002292926\right) \\
\text { SLC14A }\end{array}$ & $\begin{array}{c}\text { URE } \\
(\text { XP_002296690) }\end{array}$ & \\
\hline $\begin{array}{l}\text { Phaeodactylum tricornutum } \\
\text { (pennate diatom; } \\
\text { Bowler et al. 2008) }\end{array}$ & $\begin{array}{c}\text { DUR 3A-B } \\
\left(X P \_002180571\right. \\
\left.X P \_002180573\right) \\
\text { SLC14A }\end{array}$ & $\begin{array}{c}\text { URE } \\
(\text { XP_002183086) }\end{array}$ & \\
\hline $\begin{array}{l}\text { Haptophytes } \\
\text { Emiliania huxleyi }\end{array}$ & $\begin{array}{c}\text { DUR 3A-C } \\
(\text { PI\#440179[isoA] } \\
460978[\text { iso }], \\
217311[\text { isoC }]) \\
\text { SLC14A }\end{array}$ & $\begin{array}{c}\text { URE } \\
(\text { PI\#42377) }\end{array}$ & \\
\hline $\begin{array}{l}\text { Pelagophytes } \\
\text { Aureococcus anophagefferens }\end{array}$ & $\begin{array}{c}\text { DUR3 } \\
\text { (PI\#71789) }\end{array}$ & $\begin{array}{c}\text { URE } \\
\text { (PI\#54430 and 77851) }\end{array}$ & \\
\hline \multicolumn{3}{|l|}{$\begin{array}{l}\text { Prasinopnytes } \\
\text { Micromonas pusilla (CCMP 1545) }\end{array}$} & \\
\hline Micromonas sp. (RCC299) & $\begin{array}{c}\text { DUR3 } \\
(\text { ACO64416) }\end{array}$ & $\begin{array}{c}\mathrm{URE} \\
(\text { ACO69704) }\end{array}$ & \\
\hline Ostreococcus tauri & $\begin{array}{c}\text { DUR3 } \\
(C A L 57595)\end{array}$ & $\begin{array}{c}\text { URE } \\
(C A L 5759)\end{array}$ & \\
\hline Ostreococcus lucimarinus & $\begin{array}{c}\text { DUR3 } \\
\left(X P_{-} 001416230\right)\end{array}$ & $\begin{array}{c}\text { URE } \\
\left(X P_{-} 001416478\right)\end{array}$ & \\
\hline \multicolumn{4}{|l|}{ Chlorophytes } \\
\hline Chlamydomonas reinhardtii & $\begin{array}{c}\text { DUR3A-C } \\
\left(\mathrm{XP}_{-} \text {001702308 [isoA] }\right. \\
\text { XP_001702309 [isoB] } \\
\text { XP00170417 [isoC]) }\end{array}$ & & $\begin{array}{c}\text { DUR1 } \\
\left(X P_{-} 001702324\right) \\
\text { DUR2 } \\
\left(X P_{-} 001702307\right)\end{array}$ \\
\hline
\end{tabular}

${ }^{\mathrm{a}} \mathrm{OTC}$ - Another name for the enzyme is ornithine carbamoyltransferase; ${ }^{\mathrm{b}}$ Sequence given by JGI for CPS for Ostreococcus tauri shows up as for Ostreococcus lucimarinus in GenBank 
(http://genome.jgi-psf.org/), then BLAST searches to confirm homology (via identity\%, scores, and e-values) to annotated genes in June 2009. Some enzymes have several subunits, but for consistency only genes with chosen protein domains (IPR) are listed. Accession numbers or Protein ID (PI\#) are provided in italics. An empty box does not necessarily indicate absence of the gene; possibly the gene has not yet been annotated in the relevant database

\begin{tabular}{|c|c|c|c|c|c|c|}
\hline \multirow[b]{2}{*}{$\begin{array}{l}\text { Carbamoyl- } \\
\text { phosphate } \\
\text { synthetase }\end{array}$} & \multirow[b]{2}{*}{$\begin{array}{l}\text { Ornithine } \\
\text { transcarb- } \\
\text { amylase }^{\mathrm{a}}\end{array}$} & \multirow{2}{*}{$\begin{array}{c}\text { Urea cycle } \\
\text { Arginase }\end{array}$} & \multirow[b]{2}{*}{$\begin{array}{l}\text { Argino- } \\
\text { succinate } \\
\text { lyase }\end{array}$} & \multirow[b]{2}{*}{$\begin{array}{c}\text { Argino- } \\
\text { succinate } \\
\text { synthetase }\end{array}$} & \multicolumn{2}{|c|}{${ }_{-}$Purine catabolism } \\
\hline & & & & & $\begin{array}{c}\text { Purine } \\
\text { transporter } \\
\text { (xanthinine } \\
\text { uracil permease) }\end{array}$ & $\begin{array}{c}\text { Guanine } \\
\text { deaminase }\end{array}$ \\
\hline IPR005480 & IPR002292 & IPR006035 & IPR000362 & IPR001518 & IPR000643 & IPR006680 \\
\hline
\end{tabular}

\begin{tabular}{|c|c|c|}
\hline $\begin{array}{c}\text { CPS } \\
(B A A 10403)\end{array}$ & $\begin{array}{c}\text { OTC } \\
\left(N P_{-} 442776\right)\end{array}$ & $\begin{array}{c}\text { ARG } \\
\left(N P_{-} 440030\right)\end{array}$ \\
\hline $\begin{array}{c}\text { CPS } \\
\left(N P_{-} 896923\right)\end{array}$ & $\begin{array}{c}\text { OTC } \\
\left(N P \_897679\right)\end{array}$ & $\begin{array}{c}\text { ARG } \\
\left(N P \_898511\right)\end{array}$ \\
\hline $\begin{array}{c}\text { CPS } \\
\left(N P_{-} 487849\right)\end{array}$ & $\begin{array}{c}\text { OTC } \\
\left(N P \_488947\right)\end{array}$ & \\
\hline $\begin{array}{c}\text { CPS } \\
\left(Y P_{-} 001660056\right)\end{array}$ & $\begin{array}{c}\text { OTC } \\
\left(Y P_{-} 001660424\right)\end{array}$ & $\begin{array}{c}\text { ARG } \\
\left(Y P_{-} 001659724\right) \\
\left(Y P_{-} 001659732\right)\end{array}$ \\
\hline $\begin{array}{c}\text { CPS } \\
\left(N P_{-} 892943\right)\end{array}$ & $\begin{array}{c}\text { OTC } \\
\left(N P \_893380\right)\end{array}$ & $\begin{array}{c}\text { ARG } \\
\left(N P \_893803\right)\end{array}$ \\
\hline
\end{tabular}

$\begin{array}{cc}\text { CPS } & \text { OTC } \\ (\text { YP_001803454) } & (\text { YP_001804665) } \\ \text { CPS } & \text { OTC } \\ \left(Y P_{-} 722523\right) & \left(Y P_{-} 721117\right)\end{array}$

\begin{tabular}{|c|c|c|c|c|c|c|}
\hline $\begin{array}{c}\text { CPS } \\
\left(X P_{-} 002289336\right)\end{array}$ & $\begin{array}{c}\text { OTC } \\
\left(X P_{-} 002286586\right)\end{array}$ & $\begin{array}{c}\text { ARG } \\
(\text { XP_002296117) }\end{array}$ & $\begin{array}{c}\text { ASL } \\
(\text { XP_002291698) }\end{array}$ & $\begin{array}{c}\text { ASS } \\
\left(X P_{-} 002295518\right)\end{array}$ & $\begin{array}{c}\text { URA } \\
\left(X P_{-} \text {002295239) }\right.\end{array}$ & \\
\hline $\begin{array}{c}\text { CPS } \\
\left(X P_{-} 002183539\right)\end{array}$ & $\begin{array}{c}\text { OTC } \\
(\text { XP_002184453) }\end{array}$ & $\begin{array}{c}\text { ARG } \\
\left(X P_{0} 002182650\right)\end{array}$ & $\begin{array}{c}\text { ASL } \\
\left(X P \_002178853\right)\end{array}$ & $\begin{array}{c}\text { ASS } \\
\left(X P \_002185721\right)\end{array}$ & $\begin{array}{c}\text { URA } \\
\left(X P_{-} 002185427\right)\end{array}$ & $\begin{array}{c}\text { GDA } \\
\left(X P \_002178558\right)\end{array}$ \\
\hline $\begin{array}{c}\text { CPS } \\
(\text { PI\#422007) }\end{array}$ & $\begin{array}{c}\text { OTC } \\
(\text { PI\#236460) }\end{array}$ & $\begin{array}{c}\text { ARG } \\
(\text { PI\#434747) }\end{array}$ & $\begin{array}{c}\text { ASL } \\
(\text { PI\#456474) }\end{array}$ & $\begin{array}{c}\text { ASS } \\
\text { (PI\#441299) }\end{array}$ & $\begin{array}{c}\text { URA } \\
\text { (PI\#203630) }\end{array}$ & $\begin{array}{c}\text { GDA } \\
(P I \# 42202 \\
\text { and } 42244)\end{array}$ \\
\hline $\begin{array}{c}\text { CPS } \\
(\text { PI\#38679) }\end{array}$ & $\begin{array}{c}\text { OTC } \\
(\text { PI\#33293) }\end{array}$ & $\begin{array}{c}\text { ARG } \\
(\text { PI\#77903) }\end{array}$ & $\begin{array}{c}\text { ASL } \\
\text { (PI\#32664) }\end{array}$ & $\begin{array}{c}\text { ASS } \\
(\text { PI\#26092) }\end{array}$ & $\begin{array}{c}\text { URA } \\
\text { (PI\#55502) }\end{array}$ & $\begin{array}{c}\text { GDA } \\
(P I \# 70268)\end{array}$ \\
\hline $\begin{array}{c}\text { CPS } \\
(\text { EEH57359) }\end{array}$ & $\begin{array}{c}\text { OTC } \\
(\text { EEH59886) }\end{array}$ & $\begin{array}{c}\text { ARG } \\
(\text { EEH57601) }\end{array}$ & $\begin{array}{c}\text { ASL } \\
(\text { EH60517) }\end{array}$ & $\begin{array}{c}\text { ASS } \\
(\text { EEH52445) }\end{array}$ & & \\
\hline $\begin{array}{c}\text { CPS } \\
(\text { ACO62638) }\end{array}$ & $\begin{array}{c}\text { OTC } \\
(\text { ACO68586) }\end{array}$ & $\begin{array}{c}\mathrm{ARG} \\
(\text { ACO62762) }\end{array}$ & $\begin{array}{c}\text { ASL } \\
(\text { ACO61144) }\end{array}$ & $\begin{array}{c}\text { ASS } \\
(\text { ACO67580) }\end{array}$ & $\begin{array}{c}\text { URA } \\
\text { (ACO69126) }\end{array}$ & \\
\hline $\begin{array}{c}\text { CPS } \\
\left(X_{-} P_{001419372}\right)^{\mathrm{b}}\end{array}$ & $\begin{array}{c}\text { OTC } \\
(C A L 50057)\end{array}$ & $\begin{array}{c}\text { ARG } \\
(C A L 54440)\end{array}$ & $\begin{array}{c}\text { ASL } \\
\text { (CAL57392) }\end{array}$ & $\begin{array}{c}\text { ASS } \\
(C A L 58290)\end{array}$ & & \\
\hline $\begin{array}{c}\text { CPS } \\
\left(X P_{-} 001419372\right)\end{array}$ & $\begin{array}{c}\text { OTC } \\
\left(X P_{-} 001415432\right)\end{array}$ & $\begin{array}{c}\text { ARG } \\
(\text { XP_001417251) }\end{array}$ & $\begin{array}{c}\text { ASL } \\
\left(X P \_001420706\right)\end{array}$ & $\begin{array}{c}\text { ASS } \\
\left(X P_{-} 001421662\right)\end{array}$ & & \\
\hline $\begin{array}{c}\text { CPS } \\
(\text { XP_001691359) }\end{array}$ & $\begin{array}{c}\text { OTC } \\
(\text { XP_001690929) }\end{array}$ & $\begin{array}{c}\text { ARG } \\
\left(X P_{-} 001702430\right)\end{array}$ & $\begin{array}{c}\text { ASL } \\
(\text { XP_001689515) }\end{array}$ & $\begin{array}{c}\text { ASS } \\
\left(X P_{-} 001696749\right)\end{array}$ & $\begin{array}{c}\text { URA } \\
\left(X P_{-} 001702660\right)\end{array}$ & $\begin{array}{c}\text { GDA } \\
(\text { XP_001695623) }\end{array}$ \\
\hline
\end{tabular}




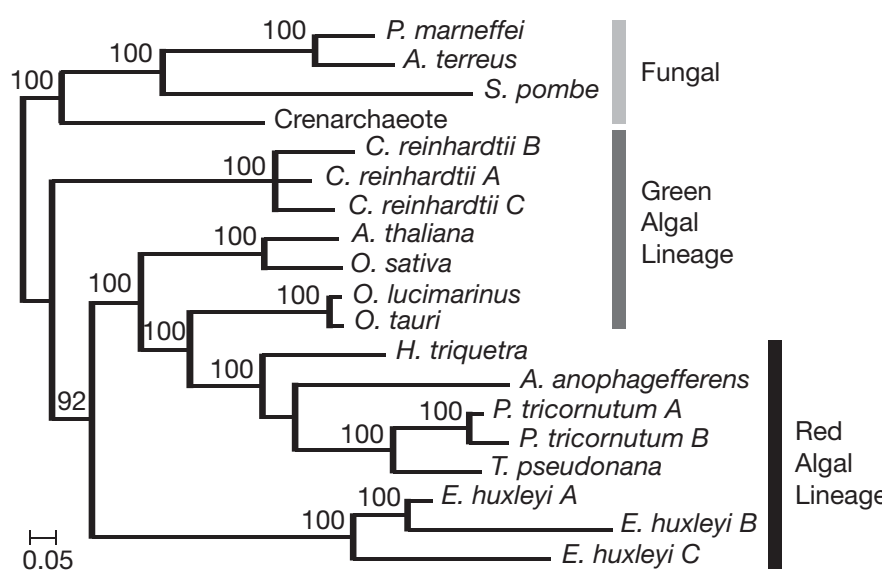

Fig. 2. Unrooted phylogenetic tree of DUR3 protein sequences (approx. 700 amino acids) aligned with the CLUSTAL W multiple sequence alignment algorithm (Thompson et al. 1994) and constructed with MrBayes 3.1 (Ronquist \& Huelsenbeck 2003). The scale bar shows number of substitutions per site. The protein sequence of Heterocapsa triquetra was created from 4 separate expressed sequence tag (EST) sequences deposited in GenBank. Dark shading indicates red algal lineages, medium gray shading indicates green algal lineages, and light gray shading represents fungal sequences and the Crenarchaeote sequence. Full scientific names are Arabidopsis thaliana, Aspergillus terreus, Aureococcus anophagefferens, Chlamydomonas reinhardtii, Emiliania huxleyi, Heterocapsa triquetra, Ostreococcus lucimarinus, Oryza sativa, Ostreococcus tauri, Penicillium marneffei, Phaeodactylum tricornutum, Schizosaccharomyces pombe and Thalassiosira pseudonana

transporters (Raunser et al. 2009). In vascular plants, urea uptake is thought primarily to occur through the high-affinity transporter DUR3, but when urea concentrations are high, low-affinity transporters such as MIPs may become more important (Wang et al. 2008). Sequence similarity searches have revealed that some marine phytoplankton genomes contain urea transporter (SLC14A) homologues. Emiliania huxleyi has one, and Thalassiosira pseudonana has 2 urea transporter-type transporters (Table 2). Many pathogenic bacteria have urea belonging to the urea/amide or urea transporter/SLC14A families (Raunser et al. 2009), and basic local alignment search tool (BLAST) searches suggest that urea transporter homologues might also be present in a variety of nonpathogenic bacteria (results not shown), although their function remains to be proven. Berg et al. (2008) also suggested that AaNAR1.3 might be a urea transporter in phytoplankton, as expression of this gene was higher in Aureococcus cells grown on urea than in any other $\mathrm{N}$ source. In bacteria, NAR1.3 has been characterized as a formate/ $\mathrm{NO}_{2}{ }^{-}$transporter, but it has a different and not well-understood function in the green alga Chlamydomonas reinhardtii, where it does not transport $\mathrm{NO}_{2}{ }^{-}$or $\mathrm{NO}_{3}{ }^{-}$(Mariscal et al. 2006).
In higher plants, urea is metabolized quickly and does not accumulate in the cytosol. If urea were stored in the cell, then intracellular urea transporters would be essential for moving urea accumulating in the cytosol into storage vacuoles, in order to prevent possible toxicity to the cell, but there are no reports of any vacuolar urea concentrations in higher plants nor channel-like active tonoplast/vacuolar transporters (Wang et al. 2008). In contrast to higher plants, cellular accumulation of urea up to $280 \mathrm{mM}-\mathrm{N}$ occurs in some dinoflagellates such as Prorocentrum minimum and Karlodinium veneficum (Solomon \& Glibert 2008). Determining the urea storage mechanisms used by organisms that can accumulate urea would be an interesting avenue of research and would be aided by the generation of many more sequence data for dinoflagellates.

\section{Regulation of urea uptake}

Urea transporters, like those described above, bring new $\mathrm{N}$ (that is, $\mathrm{N}$ that can contribute to increases in biomass) into the microbial cell, so it is not surprising that culture studies have shown that urea uptake and expression of UTs in bacteria and phytoplankton are influenced by the availability of alternative $\mathrm{N}$ substrates, especially $\mathrm{NH}_{4}{ }^{+}$. In Corynebacterium glutamicum, expression of the UT (urt) genes increases when growth is limited by N supply (Silberbach \& Burkovski 2006), and in Deleya (now Halomonas) venusta HG1, urea uptake was lowest in cells grown on $\mathrm{NH}_{4}{ }^{+}$and highest in cells grown on $\mathrm{NO}_{3}{ }^{-}$and in cells deprived of $\mathrm{N}$ (Jahns 1992b). Phytoplankton, particularly diatoms, grown under $\mathrm{N}$-starved or N-replete conditions consistently have shown decreased rates of urea uptake after the addition of $\mathrm{NH}_{4}{ }^{+}$ and/or $\mathrm{NO}_{3}{ }^{-}$to cultures (Rees \& Syrett 1979, Lund 1987, Lomas 2004, Jauzein et al. 2008a). For example, in the N-starved Phaeodactylum tricornutum, urea uptake was inhibited after transfer to a medium containing $\mathrm{NH}_{4}{ }^{+}$ (Rees \& Syrett 1979, Molloy \& Syrett 1988), and in Skeletonema costatum, Lund (1987) observed a decrease of from 82 to $84 \%$ in urea uptake $3 \mathrm{~h}$ after the addition of either $10 \mu \mathrm{M}-\mathrm{N} \mathrm{NO}_{3}{ }^{-}$or $\mathrm{NH}_{4}{ }^{+}$. As in these diatoms, urea uptake in dinoflagellates may be inhibited by inorganic $\mathrm{N}$ substrates. In a comparison of different strains of the dinoflagellate Alexandrium catenella, strong inhibition of urea uptake by $\mathrm{NH}_{4}{ }^{+}$was observed in only one strain, which may be explained by the adaptation of that strain to a low $\mathrm{NH}_{4}{ }^{+}$and high urea environment as compared to the other strains (Jauzein et al. 2008b).

Similar observations of the influence of $\mathrm{NH}_{4}{ }^{+}$on rates of urea uptake have been made in many field studies. Urea uptake rates generally decrease after the addition of $\mathrm{NH}_{4}{ }^{+}$or with increasing ambient $\mathrm{NH}_{4}{ }^{+}$con- 


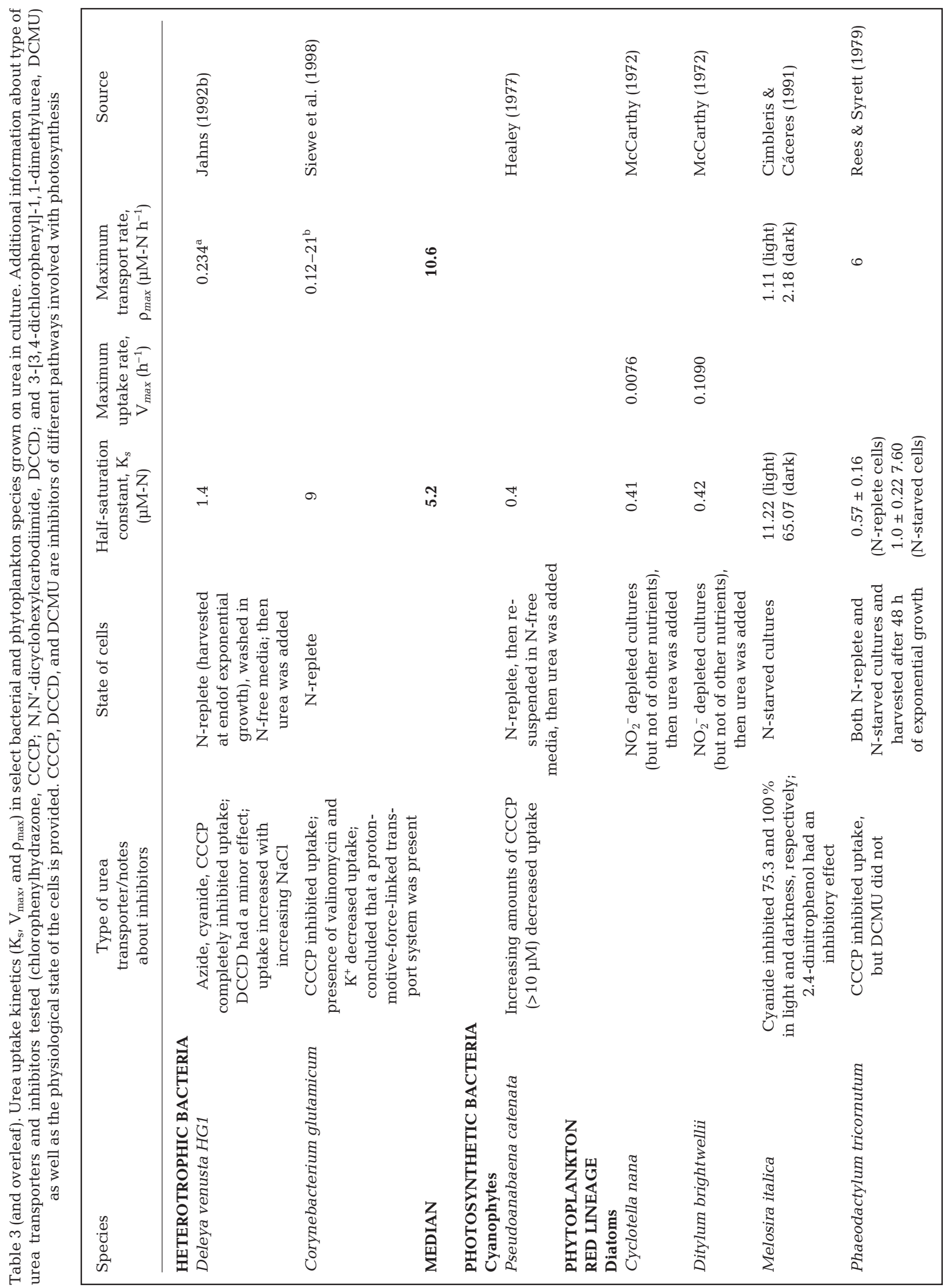




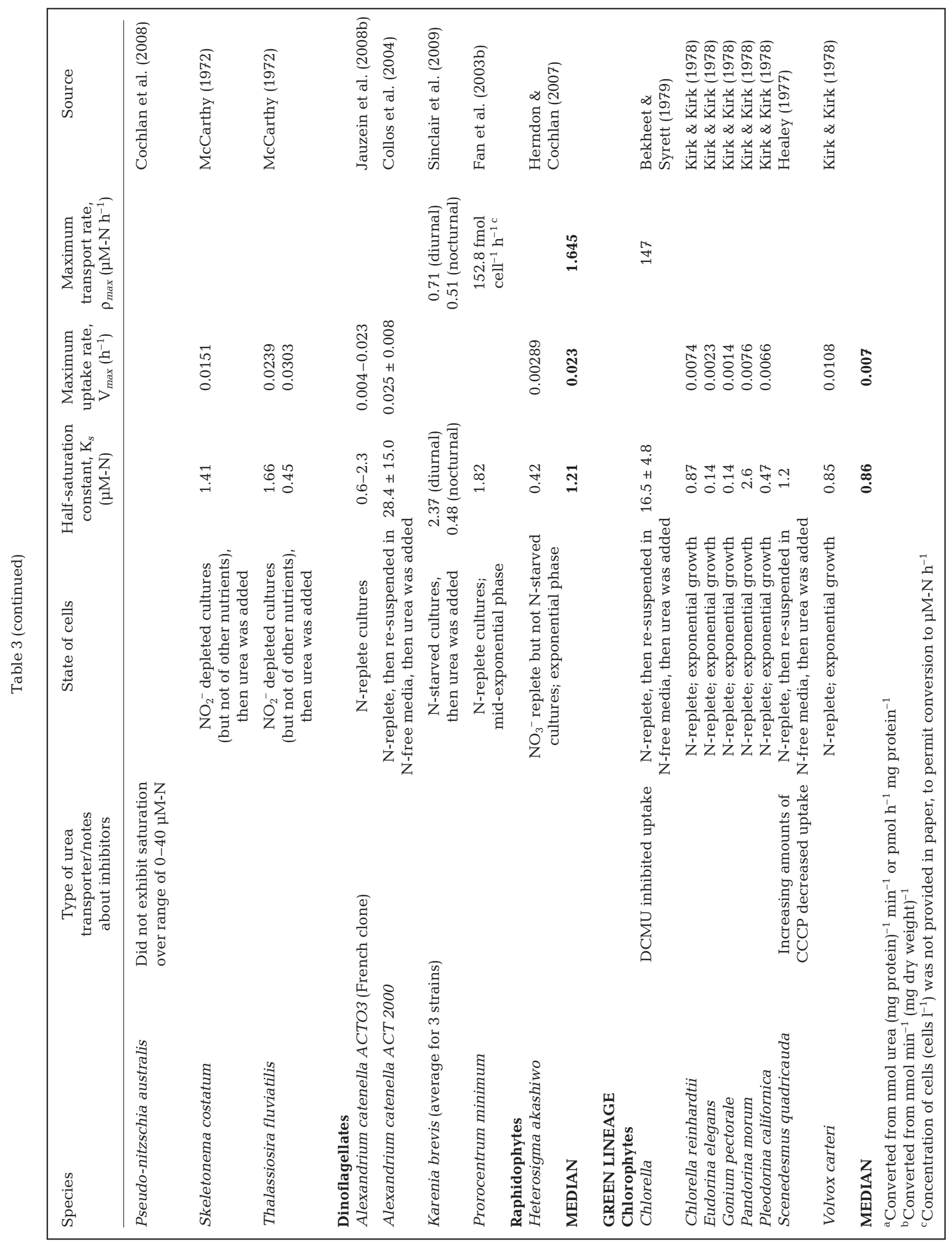


centrations. For example, urea uptake rates decreased after the addition of $20 \mu \mathrm{M}-\mathrm{N} \mathrm{NH}_{4}{ }^{+}$but not after the addition of $20 \mu \mathrm{M}-\mathrm{N} \mathrm{NO}_{3}{ }^{-}$in field incubations of Baltic seawater (Tamminen \& Irmisch 1996). Urea uptake was found to be inhibited or repressed by $\mathrm{NH}_{4}{ }^{+}$at concentrations higher than 1 to $2 \mu \mathrm{M}-\mathrm{N}$ in Oslofjord, Norway (Kristiansen 1983), $40 \mu \mathrm{M}-\mathrm{N}$ in the Neuse Estuary, NC (Twomey et al. 2005), and $5 \mu \mathrm{M}-\mathrm{N}$ in the Chesapeake Bay (Solomon 2006; Fig. 3).

Alteration of transporter activity is the principal mechanism underlying the broadly observed repression of urea uptake by $\mathrm{NH}_{4}{ }^{+}$in bacteria and phytoplankton in culture and natural plankton communities (e.g. Rees \& Syrett 1979, Lund 1987, Lomas 2004, Jauzein et al. 2008a). For example, Berg et al. (2008) found that the expression of the urea active transporter gene (AaDUR3) in Aureococcus anophagefferens was 20 - to 50 -fold higher in cultures grown on urea compared with $\mathrm{NO}_{3}{ }^{-}$and $\mathrm{NH}_{4}{ }^{+}$, respectively. In Corynebacterium glutamicum, expression of the urt genes is controlled by $\mathrm{N}$ availability via the transcription regulator AmtR (Silberbach \& Burkovski 2006), and in Cyanobacteria as diverse as Anabaena and Prochlorococcus the urt genes are regulated by $\mathrm{N}$ availability via the global $\mathrm{N}$ transcription regulator NtcA (see below; Valladares et al. 2002, Su et al. 2005, Tolonen et al. 2006). More studies are needed to investigate differences in regulation and kinetics of urea uptake among different bacterial and phytoplankton taxa and strains from a variety of environments with varying $\mathrm{N}$ concentrations (Burkholder \& Glibert 2006, 2009).

Another environmental factor that may influence rates of urea uptake is irradiance. In typical aquatic ecosystems, most urea uptake occurs via active membrane transporters that require energy. The energy for urea uptake may be obtained from photophosphorylation in phytoplankton during the day (Rees \& Syrett 1979, Siewe et al. 1998, Beckers et al. 2004) and from oxidative phosphorylation in heterotrophs or phytoplankton during the night (Cimbleris \& Cáceres 1991). In Chesapeake Bay plankton, a diel pattern in urea uptake was observed with the highest rates of urea uptake in mid-afternoon and the lowest rates during the night (Bronk et al. 1998). However, urea uptake can take place during the dark in dinoflagellatedominated assemblages (Kudela \& Cochlan 2000, Fan \& Glibert 2005, Sinclair et al. 2009). In the Chesapeake Bay plume, urea uptake represented a larger proportion of total $\mathrm{N}$ utilization during the night than during the day, because utilization of $\mathrm{NO}_{3}{ }^{-}$and $\mathrm{NH}_{4}{ }^{+}$decreased more at night (Glibert et al. 1991). Urea uptake increased with increasing irradiance during a Prorocentrum minimum bloom in the Choptank River in spite of the fact that urea uptake in this species is not light-dependent on short time scales (30 min; Fan \& Glibert 2005). This observation may indicate that the
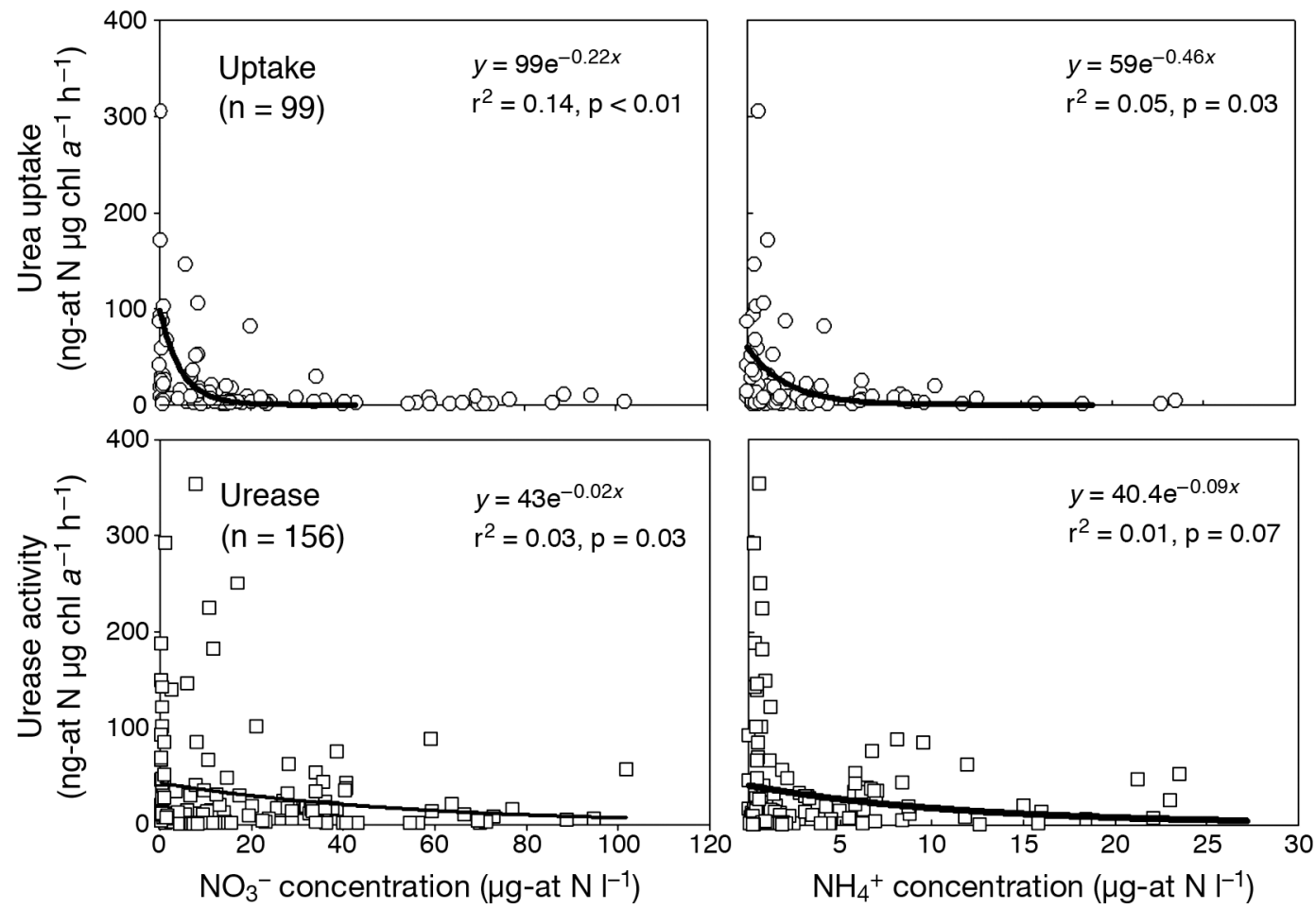

Fig. 3. Urea uptake or urease activity as a function of $\mathrm{NO}_{3}{ }^{-}$concentration and $\mathrm{NH}_{4}{ }^{+}$concentration in the Chesapeake Bay, USA (from Solomon 2006) 
capacity to convert $\mathrm{N}$ from urea that is taken up into amino acids and other components of cell biomass, which is likely to be light-dependent in phytoplankton, may also affect the rate of urea uptake. It is not yet clear how urea uptake rates are regulated by irradiance in different phytoplankton taxonomic groups.

Field studies have shown that maximum urea uptake rates occur during the summer, while minimum rates occur during the winter in various temperate estuaries (Kristiansen 1983, Glibert et al. 1991, Bronk et al. 1998, Lomas et al. 2002, Solomon 2006), which may reflect a direct effect of temperature on urea uptake, seasonal changes in plankton community composition, and lastly a seasonal decrease in microbial urea production leading to decreased availability in winter. In contrast to $\mathrm{NO}_{3}{ }^{-}, \mathrm{NH}_{4}{ }^{+}$and urea uptake rates have a positive relationship with temperature (between 5 and $30^{\circ} \mathrm{C}$ ) in diatom-dominated assemblages (Lomas \& Glibert 1999a). Urea uptake increased as a function of temperature in the diatom Melosira italica, with a $Q_{10}$ of 1.94 (Cimbleris \& Cáceres 1991). However, urea uptake remained constant over a narrower temperature range of 10 to $25^{\circ} \mathrm{C}$ for Prorocentrum minimum in the Chesapeake Bay and Neuse Estuary (Fan et al. 2003b). These findings suggest that the relationship between temperature and urea uptake may be species-dependent.

\section{The urea cycle and purine catabolism}

In addition to uptake of external urea into the cell, urea is produced intracellularly in most organisms by the urea cycle and/or by purine catabolism (Vogels \& Van der Drift 1976, Antia et al. 1991, Allen et al. 2006, Berg \& Jørgensen 2006, Wang et al. 2008). The first step in the utilization of purines as a $\mathrm{N}$ source involves the deamination of guanine to xanthine, or the deamination of adenine to hypoxanthinine, followed by the conversion of hypoxanthine to xanthine (Vogels \& Van der Drift 1976). Xanthine is then converted into uric acid by the enzyme xanthine oxidase. Uric acid is further broken down into ureides such as allantoin and allantoic acid by the enzymes uricase, allantoinase, and allantoicase (allantoate amidinohydrolase), producing urea (Vogels \& Van der Drift 1976, Garrett \& Grisham 1995, Wang et al. 2008). Interestingly, guanine appears to be more widely produced, leading to a higher availability, and therefore higher rates of uptake and catabolism, compared with adenine in the marine environment (Antia et al. 1975, Shah \& Syrett 1982, 1984, Berman et al. 1999, Berg \& Jørgensen 2006). On the basis of sequence similarity, a putative purine transporter gene, AaURA, was discovered in Aureococcus anophagefferens and shown to be highly expressed during growth on a number of different $\mathrm{N}$ sources and under N-limited conditions (Berg et al. 2008). The enzyme guanine deaminase (but not adenine deaminase) has also been identified on the basis of sequence similarity in $A$. anophagefferens, raising the possibility that AaURA may be specific for guanine or its derivative xanthine. The sequence of AaURA is similar to the xanthine uracil permease and the purine permease identified in the genomes of Thalassiosira pseudonana and Phaeodactylum tricornutum, respectively. As with $A$. anophagefferens, these 2 diatoms also have homologues of the guanine deaminase enzyme (Table 2).

Urea is also produced intracellularly by the activity of arginase, which converts arginine into ornithine (Vogels \& Van der Drift 1976, Antia et al. 1991, Allen et al. 2006, Wang et al. 2008; Fig. 1). In eukaryotic phytoplankton, arginase may function as part of a complete urea cycle, since a complete set of urea cycle genes has been identified in the diatoms Thalassiosira pseudonana and Phaeodactylum tricornutum as well as the pelagophyte Aureococcus anophagefferens and the haptophyte Emiliania huxleyi (Table 2). Cyanobacteria appear not to have a complete set of the urea cycle genes in their genomes but do contain some genes such as carbamoylphosphate synthetase and arginase (Table 2). It is currently unknown if dinoflagellates contain any urea cycle genes, as no member of this group has been sequenced to date and the relevant biochemical assays have not been performed. The activity of urea cycle enzymes has been demonstrated in bioassays with estuarine water in which the addition of amino acids or urea cycle intermediates resulted in release of urea (Berman et al. 1999, Jørgensen et al. 1999a).

The role of the urea cycle in phytoplankton metabolism and evolution is currently being discussed and investigated. The long-known function of the urea cycle in animals is to excrete excess $\mathrm{N}$ produced by $\alpha$-keto amino acid catabolism (e.g. glutamate, proline, arginine, and histidine; Garrett \& Grisham 1995, Parker et al. 2008). The discovery of the urea cycle genes in the diatom Thalassiosira pseudonana, the first eukaryotic phytoplankton genome to be sequenced, was a surprise because urea is not considered as a 'waste' product in those organisms and the $\mathrm{NH}_{4}{ }^{+}$resulting from urea catabolism is returned back to anabolic pathways that form glutamine and glutamate (Armbrust et al. 2004, Vardi et al. 2008). The urea produced via the urea cycle, in addition to regulating amino acid catabolism, may serve as an osmolyte for the cell (Armbrust et al. 2004, Allen et al. 2006). Another hypothesis about the role of the urea cycle in diatoms is that intermediates from the urea cycle contribute to other aspects of cell metabolism. For instance, ornithine is used to make spermine and spermidine, which have roles in 
silica precipitation (Armbrust et al. 2004). Phylogenic analysis of Phaeodactylum tricornutum revealed that genes involved in the urea cycle seem to have a prokaryotic origin, which suggests that those genes could have been acquired via horizontal gene transfer, but by which possible mechanism (e.g. viral infection, phagotrophy, association with organelles, or with intracellular endosymbionts) is not clear (Parker et al. 2008, Vardi et al. 2008).

\section{Intracellular catabolism of urea}

Urea, from either internal or external sources, can be broken down into $\mathrm{NH}_{4}{ }^{+}$and inorganic carbon (C) by urease (Mobley \& Hausinger 1989, Antia et al. 1991, Zehr \& Ward 2002) or by UALase (Antia et al. 1991, Hausinger 2004). Urease is by far the better-characterized enzyme of the two. Urease is a cytosolic enzyme that catalyzes the hydrolysis of urea to ammonia and carbamate. Carbamate spontaneously decomposes to yield a second molecule of ammonia and carbonic acid (Mobley \& Hausinger 1989, Mobley et al. 1995):

$$
\begin{gathered}
\mathrm{CO}-\left(\mathrm{NH}_{2}\right)_{2}+\mathrm{H}_{2} \mathrm{O} \rightarrow \mathrm{NH}_{3}+\mathrm{OH}-\mathrm{CO}-\mathrm{NH}_{2} \\
\mathrm{OH}-\mathrm{CO}-\mathrm{NH}_{2}+\mathrm{H}_{2} \mathrm{O} \rightarrow \mathrm{NH}_{3}+\mathrm{H}_{2} \mathrm{CO}_{3}
\end{gathered}
$$

At environmental pH ( 7-8), the ammonia molecule equilibrates with water and becomes protonated, forming $\mathrm{NH}_{4}{ }^{+}$. The cell then uses the $\mathrm{NH}_{4}{ }^{+}$produced by catabolism of urea for protein synthesis (Wheeler 1983, Capone 2000).

In most bacteria, including Cyanobacteria, the urease enzyme occurs as 2 small (gamma, $\gamma$, and beta, $\beta$ ), and one large (alpha, $\alpha$ ) protein subunits encoded by the ure $A$, ure $B$, and ure $C$ genes, respectively (Mobley et al. 1995). In the bacterium Helicobacter pylori, the $\gamma$ and $\beta$ subunits are fused into one protein, and the complete urease enzyme therefore has 2 subunits. In eukaryotes, all 3 subunits are fused into a single protein, encoded by the ure $A B C$ gene, where the $\mathrm{N}$ terminus is homologous to the bacterial $\gamma$ subunit, the internal sequence is homologous to the $\beta$ subunit, and the $\mathrm{C}$ terminus is homologous to the bacterial $\alpha$ subunit. There are also several accessory genes (ureD, ureE, $u r e F$, and ureG) that aid in the production of active urease by supporting the assembly of the nickel metallocenter of the enzyme (Mobley et al. 1995).

Urease genes have been found in the recently sequenced red lineage marine phytoplankton genomes, including Thalassiosira pseudonana, Phaeodactylum tricornutum, Emiliana huxleyi, and Aureococcus anophagefferens as well as in several green lineage marine phytoplankton genomes including 2 Ostreococcus and 1 Micromonas strain (RCC299; Table 2). The urease protein sequences of the red-lineage

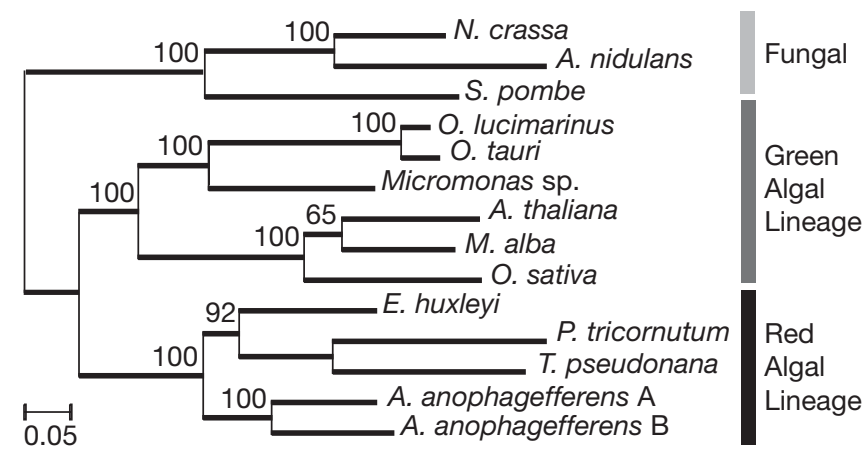

Fig. 4. Unrooted phylogenetic tree of urease protein sequences (approx. 830 amino acids) aligned with the CLUSTAL W multiple sequence alignment algorithm (Thompson et al. 1994) and constructed with MrBayes 3.1 (Ronquist \& Huelsenbeck 2003). The scale bar shows number of substitutions per site. Shading as in Fig. 2. Full scientific names are Arabidopsis thaliana, Aspergillus nidulans, Aureococcus anophagefferens, Emiliania huxleyi, Morus alba, Neurospora crassa, Ostreococcus lucimarinus, Oryza sativa, Ostreococcus tauri, Phaeodactylum tricornutum, Schizosaccharomyces pombe and Thalassiosira pseudonana

phytoplankton cluster together, whereas the greenlineage phytoplankton cluster more closely with higher plants (Fig. 4). A fragment of the ureABC gene has also been amplified from the diatom Thalassiosira oceanica, 2 prymnesiophytes (Pseudoisochrysis paradoxa and the unidentified species CCMP 1249), and the eustigmatophyte Nannochloropsis gaditana using primers for 2 highly conserved motifs in the ureC region (Baker et al. 2009). The number, location, and length of introns in the ure $A B C$ gene of phytoplankton vary but are more similar among more closely related taxa. A. anophagefferens has 3 similar (less than 5\% different) ure $A B C$ gene loci in its genome, though one of these (Protein ID 72133) appears to be truncated (missing the N-terminal region; Table 2). In contrast, the diatoms $P$. tricornutum and $T$. pseudonana, the haptophyte E. huxleyi, and other marine phytoplankton genomes sequenced to date each have only one ure $A B C$ gene (Baker et al. 2009; Table 2).

Urease genes were found by protein-protein BLAST in about one third (454 of 1331) of the prokaryotic genomes available in GenBank (last searched December 2008; Table 4). Urease may be absent from some major groups of bacteria (e.g. Spirochaetes), although sequencing of additional genomes may reveal its presence in at least some members. In other groups, urease may be restricted to one or a few genera or families (e.g. among the Bacteroidetes, Chlamydiae, Tenericutes, and Archaea), while in some groups urease is much more common and widespread (e.g. among the Actinobacteria, Cyanobacteria, and Proteobacteria). Most ureolytic bacteria have only one copy of the ure 
Table 4. Distribution of urease among sequenced prokaryotic genomes. Values are the percent of genomes, species, or genera in each group that contain a urease gene (determined by protein-protein BLAST); values in parentheses are the number with urease/total number of genomes. Data from GenBank, last searched December 2008

\begin{tabular}{|c|c|c|c|}
\hline Group & $\begin{array}{l}\text { \% urease } \\
\text { genome }\end{array}$ & $\begin{array}{l}\% \text { urease } \\
\text { species }\end{array}$ & $\begin{array}{c}\% \text { urease } \\
\text { genus }\end{array}$ \\
\hline \multicolumn{4}{|l|}{ BACTERIA } \\
\hline Actinobacteria $^{\mathrm{f}}$ & $59(42 / 71)$ & $58(33 / 57)$ & $46(12 / 26)$ \\
\hline Aquificae & $0(0 / 6)$ & $0(0 / 6)$ & $0(0 / 5)$ \\
\hline Bacteroidetes/Chlorobi $^{\mathrm{a}}$ & $4(2 / 56)$ & $4(2 / 51)$ & $7(2 / 27)$ \\
\hline Chlamydiae/Verrucomicrobia ${ }^{\mathrm{b}}$ & $10(2 / 21)$ & $13(2 / 15)$ & $10(1 / 10)$ \\
\hline Chloroflexi & $18(2 / 11)$ & $18(2 / 11)$ & $40(2 / 5)$ \\
\hline Cyanobacteria & $73(35 / 48)$ & $79(11 / 14)$ & $80(12 / 15)$ \\
\hline Deinococcus-Thermus & $20(1 / 5)$ & $25(1 / 4)$ & $50(1 / 2)$ \\
\hline Dictyoglomi & $0(0 / 1)$ & $0(0 / 1)$ & $0(0 / 1)$ \\
\hline Fibrobacteres/Acidobacteria & $0(0 / 5)$ & $0(0 / 5)$ & $0(0 / 4)$ \\
\hline Firmicutes & $15(40 / 272)$ & $17(22 / 127)$ & $24(11 / 46)$ \\
\hline Fusobacteria & $0(0 / 3)$ & $0(0 / 1)$ & $0(0 / 1)$ \\
\hline Nitrospirae & $0(0 / 1)$ & $0(0 / 1)$ & $0(0 / 1)$ \\
\hline Planctomycetes & $0(0 / 3)$ & $0(0 / 3)$ & $0(0 / 3)$ \\
\hline Alphaproteobacteria $^{\mathrm{f}}$ & $51(71 / 139)$ & $52(55 / 105)$ & $54(32 / 59)$ \\
\hline Betaproteobacteria $^{\mathrm{f}}$ & $81(83 / 103)$ & $75(38 / 51)$ & $69(18 / 26)$ \\
\hline Gammaproteobacteria $^{\mathrm{f}}$ & $37(118 / 316)$ & $38(53 / 140)$ & $50(35 / 70)$ \\
\hline Delta/epsilonproteobacteria $^{\mathrm{f}}$ & $23(14 / 62)$ & $15(6 / 40)$ & $18(4 / 22)$ \\
\hline Other Proteobacteria & $50(1 / 2)$ & $50(1 / 2)$ & $50(1 / 2)$ \\
\hline Spirochaetes & $0(0 / 32)$ & $0(0 / 15)$ & $0(0 / 3)$ \\
\hline Tenericutes ${ }^{\mathrm{c}}$ & $39(14 / 36)$ & $10(2 / 21)$ & $13(1 / 8)$ \\
\hline Thermodesulfobacteria & $0(0 / 1)$ & $0(0 / 1)$ & $0(0 / 1)$ \\
\hline Thermotogae & $0(0 / 8)$ & $0(0 / 7)$ & $0(0 / 4)$ \\
\hline \multicolumn{4}{|l|}{ ARCHEA } \\
\hline Crenarchaeota $^{\mathrm{d}}$ & $6(1 / 16)$ & $6(1 / 16)$ & $9(1 / 11)$ \\
\hline Euryarchaeota $^{\mathrm{e}}$ & $11(4 / 38)$ & $12(4 / 34)$ & $16(4 / 25)$ \\
\hline Other Archaea & $0(0 / 2)$ & $0(0 / 2)$ & $0(0 / 2)$ \\
\hline $\begin{array}{l}\text { a Only the genera Flavobacteriu } \\
{ }^{\mathrm{b}} \text { Only the Opitutaceae have ure } \\
\text { cOnly the genus Ureaplasma ho } \\
\text { d Only the genus Sulfolobus has } \\
\text { de Only some of the Halobacteria } \\
{ }^{\mathrm{d}} \text { Some members of these group }\end{array}$ & $\begin{array}{l}\text { Im and Cytopl } \\
\text { ease } \\
\text { as urease } \\
\text { urease } \\
\text { ceae have ure } \\
\text { s have more t }\end{array}$ & ga have urea & \\
\hline
\end{tabular}

et al. 1991, Hausinger 2004). UALase occurs either as a fusion of urea carboxylase (EC 6.3.4) and allophanate hydrolase (EC 3.5.1.54) proteins, or as 2 separate proteins that work together to degrade urea. In the yeast Saccharomyces cerevisiae, UALase is a single, fused protein encoded by the DUR1,2 gene, whereas in the green alga Chlamydomonas reinhardtii, which is the only sequenced eukaryotic phototroph possessing UALase, the 2 activities occur in separate proteins encoded by the DUR1 and DUR2 genes (Table 2). The ATPdependent urea carboxylase protein (located at the C-terminus of the fusion yeast protein) catalyzes the first reaction:

$$
\begin{gathered}
\mathrm{CO}-\left(\mathrm{NH}_{2}\right)_{2}+\mathrm{HCO}_{3}^{-}+\mathrm{ATP} \rightarrow \\
\left(\mathrm{NH}_{2}\right)-\mathrm{CO}-\mathrm{NH}-\mathrm{COO}^{-}+\mathrm{H}_{2} \mathrm{O}+\mathrm{ADP}+\mathrm{P}_{\mathrm{i}}
\end{gathered}
$$

whereas the allophanate hydrolase (homologous to the $\mathrm{N}$-terminal domain of the yeast protein) catalyzes the second reaction:

$$
\begin{gathered}
\left(\mathrm{NH}_{2}\right)-\mathrm{CO}-\mathrm{NH}-\mathrm{COO}^{-}+3 \mathrm{H}_{2} \mathrm{O}+\mathrm{H}^{+} \rightarrow \\
2 \mathrm{NH}_{4}^{+}+2 \mathrm{HCO}_{3}^{-}
\end{gathered}
$$

The UALase homologue (URC3,5) of Saccharomyces kluyveri has recently been characterized as an integral component of a novel pyrimidine catabolic pathway in which urea is an intermediate (Andersen et al. 2008). DUR 1,2 is also highly active on the amides acetamide and formamide (Roon \& Levenberg 1972, Kanamori et al. 2004).

Kanamori et al. (2004) reported segregated urea carboxylase and allophanate hydrolase enzyme activities in the alpha genes encoding urease, but some Proteobacteria and Actinobacteria have 2 or 3 copies. The multiple copies in a single bacterial genome are generally very different from one another $(\sim 70 \%$ nucleotide sequence identity), and whether they have distinct biochemical properties or are regulated differently remains to be investigated. Despite the large number of bacterial urease sequences (and rapidly growing number of eukaryotic urease sequences) now available, the organisms from which more than half of the urease sequences recovered directly from estuarine and open ocean seawater samples arose cannot yet be identified (Collier et al. 2009), suggesting that there is still a great deal to learn about which organisms are responsible for urea degradation in aquatic ecosystems.

The alternative pathway for urea degradation occurs via ATP: urea amidolyase (UALase; EC 3.5.1.45; Antia proteobacterium Oleomonas sagaranensis. A search of GenBank for proteins with the same predicted conserved domain structure as the urea carboxylases of Chlamydomonas and O. sagaranensis (using the Conserved Domain Architecture Retrieval Tool) revealed putative urea carboxylases in a variety of bacteria, mostly among the Proteobacteria and Actinobacteria (data not shown). This result suggests that the UALase pathway may be present in a variety of bacteria, some of which also have urease and some of which do not. The presence of UALase in bacteria dramatically broadens the taxonomic distribution of this pathway, previously thought to be restricted to some yeasts and chlorophytes (Hausinger 2004). Much more biochemical and physiological work will be required to determine what role UALase might play in the $\mathrm{N}$ metabolism of planktonic bacteria. 


\section{Regulation of urea catabolism}

In phytoplankton that have urease, a basal level of urease activity is usually always detectable, but the level of activity varies with N source (Antia et al. 1991, Collier et al. 1999, Peers et al. 2000, Dyhrman \& Anderson 2003, Lomas 2004, Solomon \& Glibert 2008), suggesting that urease activity is regulated by external or internal factors, as is urea uptake. However, the pattern of regulation may differ not only among but also within phytoplankton taxonomic groups (Fig. 5). In some organisms, lower urease activity is found in $\mathrm{NH}_{4}{ }^{+}$-grown cultures than in $\mathrm{NO}_{3}{ }^{-}$- and urea-grown cultures, as in the case of the dinoflagellates Prorocentrum minimum and Karlodinium veneficum (Fan et al. 2003a, Solomon \& Glibert 2008). In these organisms, as in many Cyanobacteria, when insufficient $\mathrm{NH}_{4}{ }^{+}$is available to meet $\mathrm{N}$ demand, urease activity may increase in response to limitation of inorganic N. In contrast, urease activity in the dinoflagellate Alexandrium fundyense was the highest in $\mathrm{N}$-starved and urea-grown cultures, lower in $\mathrm{NH}_{4}{ }^{+}$, and not detected

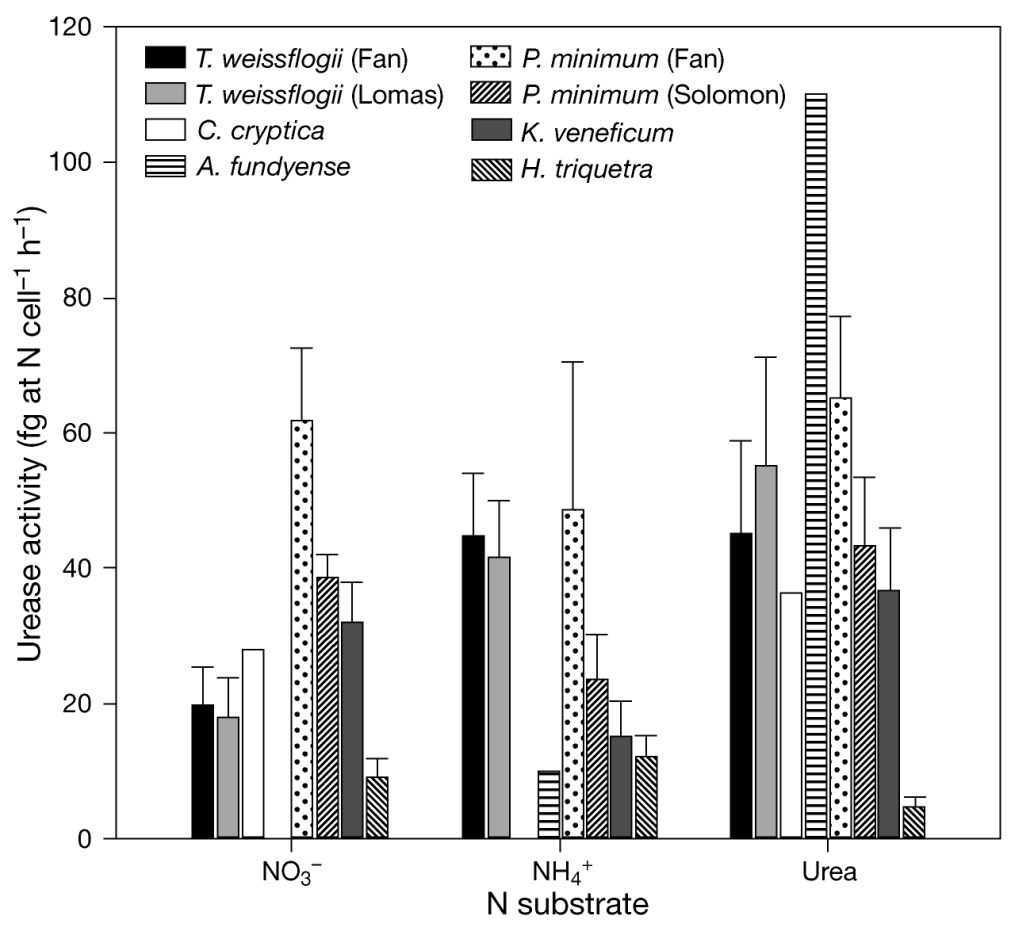

Fig. 5. Comparison of rates of urease activity in diatoms and dinoflagellates grown on different $\mathrm{N}$ substrates. Data for the diatoms Thalassiosira weissflogii were obtained from Fan et al. (2003a) and Lomas (2004), and Cyclotella cryptica from Oliveira \& Antia (1986). Data for the dinoflagellates Alexandrium fundyense were obtained from Dyhrman \& Anderson (2003), Prorocentrum minimum from Fan et al. (2003a), and P. minimum, Karlodinium veneficum, and Heterocapsa triquetra from Solomon \& Glibert (2008). Some rates were converted from $\mu \mathrm{M}$ urea hydrolyzed $\mathrm{min}^{-1}$ protein $^{-1}$ to fg-at $\mathrm{N}_{\text {cell }}^{-1} \mathrm{~h}^{-1}$ using the regression from Menden-Duer \& Lessard (2000) to obtain $\mathrm{N} \mathrm{cell}^{-1}$ and due to the fact that from 70 to $90 \%$ of cellular $\mathrm{N}$ is protein (Wheeler 1983). in $\mathrm{a} \mathrm{NO}_{3}{ }^{-}$-grown culture (Dyhrman \& Anderson 2003), while in Heterocapsa triquetra, urease activity was higher when grown on $\mathrm{NH}_{4}{ }^{+}$than on $\mathrm{NO}_{3}{ }^{-}$or urea (Solomon \& Glibert 2008). In these organisms, urease activity may be more strongly influenced by factors such as the size of the intracellular urea pool, which could change with variations in rates of urea uptake or production of urea from urea cycle activity or amino acid and purine catabolism. Differences in regulation can even be found among closely related organisms. For example, urease activity was the same regardless $\mathrm{N}$ source in one clone of the diatom Thalassiosira ssflogii (Peers et al. 2000), but down-regulated in ther clone when grown on $\mathrm{NO}_{3}{ }^{-}$(Fan et al. 2003a, as 2004). In field studies with natural phytoplankinversely related to concentrations of $\mathrm{NH}_{4}{ }^{+}$and $\mathrm{NO}_{3}{ }^{-}$ Fig. 3).

Although the presence of $\mathrm{NH}_{4}{ }^{+}$may inhibit the use of urea in many organisms, the mechanism of $\mathrm{NH}_{4}^{+}$ repression (also called $\mathrm{N}$ control) is best understood for Cyanobacteria. In Cyanobacteria, the expression of ure genes (as well as urt genes and the genes required to use a variety of other $\mathrm{N}$ sources) is generally regulated by cellular $\mathrm{N}$ status via the DNA-binding protein NtcA and the concentration of 2-oxoglutarate (Lindell \& Post 2001, Flores et al. 2005, Muro-Pastor et al. 2005, Espinosa et al. 2006). The compound 2-oxoglutarate is the C substrate used by glutamate synthetase to incorporate $\mathrm{N}$ into new amino acids, and because that is its major metabolic role, the concentration of 2-oxoglutarate measures the balance between $\mathrm{C}$ and $\mathrm{N}$ assimilation in Cyanobacteria. Within this general regulatory outline, there are differences among Cyanobacteria. For example, Synechococcus WH7805 had 2-fold lower urease activity when grown on $\mathrm{NH}_{4}{ }^{+}$compared to urea, but Synechococcus WH8112 showed no difference in urease activity on $\mathrm{NH}_{4}{ }^{+}$versus urea. Both strains had much higher urease activity when grown on $\mathrm{NO}_{3}{ }^{-}$than on urea (J. L. Collier unpubl. data). Similarly, urease expression increased in response to $\mathrm{N}$ deprivation in both of the Prochlorococcus strains studied by Tolonen et al. (2006), but there were other differences in $\mathrm{N}$ regulation between them. Urease is not under the control of NtcA in all Cyanobacteria. Instead, it appears to be expressed constitutively in Cyanobacteria that can accumulate cyanophycin (multi-L-arginyl-poly[L-aspartic acid]; Quintero et al. 2000, Valladares et al. 2002; 
note that marine Synechococcus and Prochlorococcus do not have cyanophycin). This may reflect a predominant role for urease in arginine catabolism during the
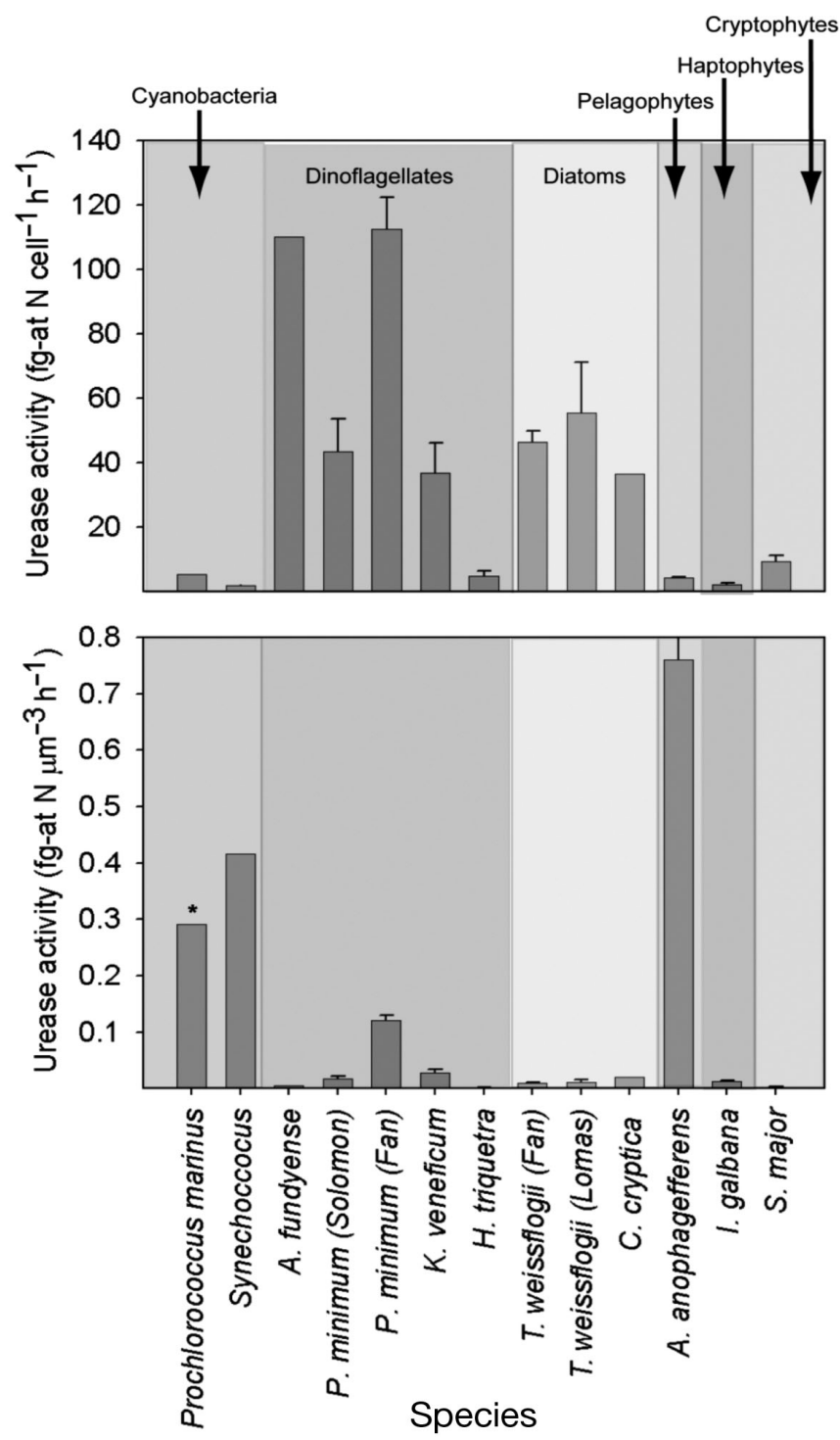

Fig. 6. Comparison of urease activity rates between different phytoplankton species grown on urea on a per cell or per cell volume basis. Data for the Cyanobacteria Prochlorococcus marinus and Synechococcus WH7805 were obtained from Palinska et al. (2000) and Collier et al. (1999), respectively. Rates were converted from $\mu \mathrm{M}$ urea hydrolyzed $\mathrm{min}^{-1}$ protein $^{-1}$ to fg-at $\mathrm{N} \mathrm{cell}^{-1} \mathrm{~h}^{-1}$ using $21.5 \mathrm{fg}_{\text {protein cell }}^{-1}$ for $P$. marinus (Zubkov \& Tarran 2005) and $500 \mathrm{fg}$ protein cell $^{-1}$ for WH7805 (Kramer \& Morris 1990). P. marinus on a per cell volume basis $\left({ }^{*}\right)$ was divided by 10 to allow for visualization of other species. Data sources of other species are described in Fig. 5. Cell volumes were calculated assuming a sphere or cylinder and diameters obtained from readings on the Coulter Counter or from CCMP. Full scientific names are Alexandrium fundyense, Aureococcus anophagefferens, Cyclotella cryptica, Heterocapsa triquetra, Isochrysis galbana, Karlodinium veneficum, Prorocentrum minimum, Storeatula major and Thalassiosira weissflogii mobilization of $\mathrm{N}$ stored in cyanophycin, rather than assimilation of $\mathrm{N}$ from external sources of urea, in cyanophycin-containing Cyanobacteria.

A variety of other bacteria also regulate the expression of ure genes in response to cellular $\mathrm{N}$ status via their global $\mathrm{N}$ regulatory systems (e.g. NTR and NAC in Klebsiella; AmtR in Corynebacterium glutamicum; TnrA, GlnR, and CodY in Bacillus subtilis; Mobley et al. 1995, Silberbach \& Burkovski 2006, Tam et al. 2007). However, different regulatory mechanisms for the expression of urease can be found in other bacteria, including regulation by the presence of urea (via the transcription regulator UreR) in Proteus and Providencia and by $\mathrm{pH}$ in Streptococcus (Mobley et al. 1995). In some bacteria, the expression of urease is constitutive (Mobley et al. 1995).

Less is known about the regulation of UALase expression, although the theme of regulation by $\mathrm{N}$ availability may be consistent. DUR1,2 is induced under $\mathrm{N}$ starvation or growth on 'poor' $\mathrm{N}$ sources (and is controlled by the transcription factor DAL80 which negatively regulates multiple $\mathrm{N}$ catabolic pathways in Saccharomyces cerevisiae) (Cunningham \& Cooper 1991). In turn, DAL80, a GATA repressor, is regulated by intracellular concentrations of the 'good' $\mathrm{N}$ sources glutamine and $\mathrm{NH}_{4}{ }^{+}$(Cunningham \& Cooper 1991, Cunningham et al. 2000, Georis et al. 2009).

Urease activity, like urea uptake, appears to have a positive relationship with temperature, in part because urease is a heat-stable enzyme (Mobley \& Hausinger 1989). In the only laboratory study that investigated temperature effects, urease activity generally increased in cultures of 3 phytoplankton species over a range of temperatures (from 0 to $50^{\circ} \mathrm{C}$ ). The study concluded that the optimal in vitro temperature for urease activity in Aureococcus anophagefferens $\left(\sim 50^{\circ} \mathrm{C}\right)$ was higher than that for Thalassiosira weissflogii and Prorocentrum minimum $\left(\sim 20^{\circ} \mathrm{C}_{i}\right.$ Fan et al. 2003a). In the field, rates of urease activity typically peak in summer months and are up to 5 -fold higher than rates in fall or spring (Siuda \& Chróst 2006, Solomon 2006). This seasonally recurring pattern could reflect direct or indirect effects of temperature, plankton community composition, and/or urea concentration. Higher temperatures in summer result in a greater level of heterotrophic bacterial activity and therefore increased urea production from purines than in other seasons (Berg \& Jørgensen 2006). Phytoplankton taxa that tend to dominate during the summer such as dinoflagellates and Cyanobacteria may be utilizing this increased supply of urea. A synthesis of published rates of urease activity in culture suggests that dinoflagellates have higher urease activities on a per cell basis, while Cyanobacteria and one pelagophyte, Aureococcus anophagefferens, have higher 
rates of urease activity on a per cell volume basis than other phytoplankton taxonomic groups (Solomon 2006, Glibert et al. 2008; Fig. 6). However, in field studies with diverse plankton assemblages, it has been difficult to distinguish which phytoplankton taxonomic group contributes the largest percentage of community urease activity (Solomon 2006). Urease activity in larger phytoplankton may be inhibited from a lack of $\mathrm{Ni}^{2+}$ (needed for the metallocenter of urease; Oliveira \& Antia 1986, Egleston \& Morel 2008) or by metabolites produced in the cell (urease activity measured in in vitro assays decreases with increasing biomass in the assay; Solomon et al. 2007). It has also been observed that most urea uptake in the field may be by eukaryotic phytoplankton, while much of the urease activity may be due to smaller phytoplankton and bacteria (Solomon 2006).

In summary, urea is primarily transported into the cell by high-affinity, active membrane transporters (encoded by the urt or DUR3 genes). The rate of transport of urea into the cell is measured as urea uptake activity. Urea is also produced internally as a byproduct of the urea cycle, amino acid catabolism (Mobley \& Hausinger 1989, Antia et al. 1991, Siewe et al. 1998, Beckers et al. 2004), and purine catabolism (Vogels \& Van der Drift 1976, McIninch et al. 2003, Allen et al. 2006). Urea produced from catabolism/salvage pathways can be either excreted into the environment (Bronk et al. 1998, Jørgensen et al. 1999b, Berg \& Jørgensen 2006) or further hydrolyzed to $\mathrm{NH}_{4}{ }^{+}$and $\mathrm{CO}_{2}$ by the enzyme urease (encoded by the ure genes; Mobley \& Hausinger 1989, Antia et al. 1991, Zehr \& Ward 2002) or by ATP: urea amidolyase (UALase, encoded by DUR1,2; Antia et al. 1991, Hausinger 2004). $\mathrm{NH}_{4}{ }^{+}$produced by catabolism of urea can be used for protein synthesis (Wheeler 1983, Capone 2000), captured by the urea cycle (Allen et al. 2006), or enter other metabolic pathways in the cell.

\section{FUTURE DIRECTIONS IN UNDERSTANDING UREA METABOLISM AND REGULATION IN PHYTOPLANKTON AND BACTERIA}

\section{Phytoplankton genome sequences}

Elucidation of the role of urea in bacterial and phytoplankton physiology is complicated by the facts that there are both external and internal sources of urea and that urea is involved in several metabolic pathways in the microbial cell (Fig. 1). The recent availability of genome sequences from several types of phytoplankton has offered a great deal of insight into the role of urea in phytoplankton metabolism. One phytoplankton taxon that plays an important part in urea uti- lization in marine ecosystems, but has not had a genome completely sequenced yet, is the dinoflagellates (Kudela \& Cochlan 2000, Collos et al. 2004, Jauzein et al. 2008a,b). However, expressed sequence tag (EST, short mRNA sequences) libraries totaling close to 100000 sequences from dinoflagellates, including Karenia brevis, Karlodinium veneficum, Alexandrium tamarense, and Heterocapsa triquetra, have been deposited in GenBank. BLAST comparisons have not yet revealed a gene encoding urease among the dinoflagellate ESTs, and repeated attempts to amplify fragments of the urease gene from dinoflagellates, by polymerase chain reaction, have also failed (J. L. Collier unpubl. data). BLAST comparisons have also not revealed genes for UALase among the dinoflagellate ESTs, although the fact that UALase is constructed of conserved protein domains that are also found in a variety of other enzymes, combined with the relatively short sequences provided by ESTs, make this a more difficult analysis. The EST database does contain at least 3 sequences from Heterocapsa triquetra (DT386240, DT385382, DT385570) and 2 from Amphidinium carterae (CF066550, CF065106) that appear to encode DUR3-like transporters. Biochemical studies testing for the presence of urease and UALase have been limited and done only on certain species of chlorophytes, prasinophytes, 1 xanthophyte (Monodus subterraneus), 1 chrysophyte (Monochrysis lutheri), and 1 diatom (Phaeodactylum tricornutum; Leftley \& Syrett 1973, Bekheet \& Syrett 1977). The standard biochemical assay for urease detects high activity in dinoflagellates (Figs. 5 \& 6), but more detailed characterization of dinoflagellate urea-hydrolyzing activity would be worth pursing to discover whether the addition of co-factors for UALase (e.g. ATP) might reveal even higher activity. If dinoflagellates do not possess typical urease or UALase genes, they might have highly divergent urease or UALase, or a novel enzyme for urea degradation.

Genomes of 3 phytoplankton that are likely to have the ability to utilize urea are currently being sequenced; these genomes will add to our knowledge of the role urea plays in phytoplankton physiology. The diatom Fragilariopsis cylindrus and the prymnesiophyte Phaeocystis antarctica are common in polar seas and sea ice, where urea uptake rates vary between 0.5 and $9.4 \mathrm{nM}-\mathrm{N} \mathrm{h}^{-1}$ (in the seas near Antarctica; Bury et al. 1995, Waldron et al. 1995, Berman \& Bronk 2003). The soon-to-be-sequenced HAB diatom Pseudonitzschia multiseries releases the neurotoxin domoic acid and produces more domoic acid when grown on urea than on $\mathrm{NO}_{3}{ }^{-}$or $\mathrm{NH}_{4}{ }^{+}$(Howard et al. 2007). Gaining an understanding of how urea metabolism influences toxin production will be instrumental in better understanding P. multiseries blooms. 


\section{Molecular regulation of urea metabolism genes}

To better understand how urea uptake and urease activity are regulated by $\mathrm{N}$ availability and other environmental factors, work on regulation similar to that done on $\mathrm{NO}_{3}{ }^{-}$transporters and $\mathrm{NO}_{3}{ }^{-}$reductase (Lomas \& Glibert 1999, Hildebrand \& Dahlin 2000, Parker \& Armbrust 2005) is needed for urea transport, urease, UALase, and urea cycle enzymes. The abundance of transcripts encoding urea transport and urease and/or UALase enzymes may be regulated by global $\mathrm{N}$ regulators (such as NtcA, AmtR) in bacteria in response to $\mathrm{N}$ availability $\left(\mathrm{NO}_{3}{ }^{-}, \mathrm{NH}_{4}{ }^{+}\right.$, glutamine, and amino acids) in many bacteria and eukaryotic phytoplankton. Because urea transporters are located in the cell membrane, they are directly exposed to ambient $\mathrm{NO}_{3}{ }^{-}$and $\mathrm{NH}_{4}{ }^{+}$and may be more influenced by these external $\mathrm{N}$ sources than by urease or UALase (Fig. 3). Despite this general expectation, transcriptional regulation would likely differ among different microbial taxa. Understanding the molecular details of how regulation of gene expression affects urea metabolism will be most useful if this understanding is integrated with biochemical measurements of rates of urea uptake and catabolism in a variety of bacteria and phytoplankton taxa.

Many of the genes involved with urea metabolism may be involved in multiple pathways that must be taken into consideration when studying their regulation. For example, urease can be involved in both recycling 'old' $\mathrm{N}$ (from amino acid or purine catabolism) within a cell and making 'new' $\mathrm{N}$ available from purines, amino acids, or urea taken up from outside the cell. In addition to making urea available as a source of $\mathrm{N}$, urease may play other roles in some bacteria. For example, $\mathrm{NH}_{3}$-oxidizing bacteria may use the $\mathrm{NH}_{3}$ released from urea by urease as a source of energy, while other bacteria (including some pathogens) use the net increase in $\mathrm{pH}$ caused by hydrolysis of urea as a mechanism for surviving acidic conditions (Mobley et al. 1995, Koper et al. 2004). Likewise, the enzymes in the urea cycle are involved in pathways that produce intermediates that are possibly important in other aspects of cellular metabolism (Armbrust et al. 2004, Allen et al. 2006).

\section{Importance of studying urea metabolism}

A better understanding of the metabolism of urea is needed to support investigations of important issues in plankton ecology. For example, the supply of urea from anthropogenic sources has been linked to increased occurrences of HABs (e.g. Berg et al. 1997, Glibert et al. 2006, Sanderson et al. 2008). Learning exactly how HAB species are able to take advantage of the urea-N supply to outgrow their competitors is essential in managing HABs. The timing of urea inputs into these vulnerable ecosystems may be important in determining the effect of anthropogenic urea enrichment because of differences in the potential to use urea among the species present and how that potential is influenced by environmental factors such as $\mathrm{N}$ availability, temperature, and irradiance. In plankton communities that are not heavily affected by anthropogenic urea, similar information will be helpful in understanding which organisms are responsible for urea uptake and urea decomposition under various conditions. As worldwide use of urea as a $\mathrm{N}$ fertilizer and feed additive has increased more than 100 -fold in the past 4 decades, and doubled in just the past decade (Glibert et al. 2006), the effects of anthropogenic urea are expected to increase into the future, and questions regarding the physiological and biochemical regulation of this nutrient by microbes will be increasingly important to resolve.

Acknowledgements. This work was funded by the grants from the NSF Biocomplexity program (Grant OCE 9981617 to P.M.G. and OCE 0223125 to J.L.C.) and by the National Science Foundation Division of Molecular and Cellular Biosciences (Grant MCB-0818276 to C.M.S.). This is contribution number 4346 from the University of Maryland Center for Environmental Science.

\section{LITERATURE CITED}

Allen AE, Vardi A, Bowler C (2006) An ecological and evolutionary context for integrated nitrogen metabolism and related signaling pathways in marine diatoms. Curr Opin Plant Biol 9:264-273

Andersen G, Bjornberg O, Polakova S, Pynyaha Y and others (2008) A second pathway to degrade pyrimidine nucleic acid precursors in eukaryotes. J Mol Biol 380:656-666

Antia NJ, Berland BR, Bonin DJ, Maestrini SY (1975) Comparative evaluation of certain organic and inorganic sources of nitrogen for phototrophic growth of marine microalgae. J Mar Biol Assoc UK 55:519-533

Antia NJ, Harrison PJ, Oliveira L (1991) The role of dissolved organic nitrogen in phytoplankton nutrition, cell biology and ecology. Phycologia 30:1-89

Armbrust EV, Berges JA, Bowler C, Green BR and others (2004) The genome of the diatom Thalassiosira pseudonana: ecology, evolution, and metabolism. Science 306:79-86

> Baker KM, Gobler CJ, Collier JL (2009) Urease gene sequences from algae and heterotrophic bacteria in axenic and nonaxenic phytoplankton cultures. J Phycol 45: 625-634

Beckers G, Bendt AK, Kramer R, Burkovski A (2004) Molecular identification of the urea uptake system and transcriptional analysis of urea transporter- and urease-encoding genes in Corynebacterium glutamicum. J Bacteriol 186: 7645-7652

> Bekheet IA, Syrett PJ (1977) Urea-degrading enzymes in algae. Br Phycol J 12:137-143

> Bekheet IA, Syrett PJ (1979) Uptake of urea by Chlorella. New Phytol 82:179-186 
Berg GM, Jørgensen NOG (2006) Purine and pyrimidine metabolism by estuarine bacteria. Aquat Microb Ecol 42: 215-226

Berg GM, Glibert PM, Lomas MW, Burford MA (1997) Organic nitrogen uptake and growth by the chrysophyte Aureococcus anophagefferens during a brown tide event. Mar Biol 129:377-387

Berg GM, Balode M, Purina I, Bekere S, Béchemin C, Maestrini SY (2003) Plankton community composition in relation to availability and uptake of oxidized and reduced nitrogen. Aquat Microb Ecol 30:263-274

Berg GM, Shrager J, Glockner G, Arrigo KR, Grossman AR (2008) Understanding nitrogen limitation in Aureococcus anophagefferens (Pelagophyceae) through cDNA and qRT-PCR analysis. J Phycol 44:1235-1249

Berman T (1974) Urea in waters of Lake Kinneret (Sea of Galilee). Limnol Oceanogr 19:977-980

Berman T, Bronk DA (2003) Dissolved organic nitrogen: a dynamic participant in aquatic ecosystems. Aquat Microb Ecol 31:279-305

Berman T, Chava S (1999) Algal growth on organic compounds as nitrogen sources. J Plankton Res 21:1423-1437

Berman T, Béchemin C, Maestrini SY (1999) Release of ammonium and urea from dissolved organic nitrogen in aquatic ecosystems. Aquat Microb Ecol 16:295-302

Bidigare RR (1983) Nitrogen excretion by marine zooplankton. In: Carpenter EJ, Capone DG (eds) Nitrogen in the marine environment. Academic Press, New York, p 385-409

Bowler C, Allen AE, Badger JH, Grimwood J and others (2008) The Phaeodactylum genome reveals the evolutionary history of diatom genes. Nature 456:239-244

Bronk DA (2002) Dynamics of DON. In: Hansell DA, Carlson CA (eds) Biogeochemistry of dissolved organic matter. Elsevier Science, San Diego, CA, p 153-247

Bronk DA, Glibert PM, Malone TC, Banahan S, Sahlsten E (1998) Inorganic and organic nitrogen cycling in Chesapeake Bay: autotrophic versus heterotrophic processes and relationships to carbon flux. Aquat Microb Ecol 15: 177-189

Burkholder JM, Glibert PM (2006) Intraspecific variability: an important consideration in forming generalisations about toxigenic algal species. Afr J Mar Sci 28:177-180

Burkholder JM, Glibert PM (2009) The importance of intraspecific variability in harmful algae-preface to a collection of topical papers. Harmful Algae 8:744-745

Bury SJ, Owens NJP, Preston T (1995) ${ }^{13} \mathrm{C}$ and ${ }^{15} \mathrm{~N}$ uptake by phytoplankton in the marginal ice zone of the Bellinghausen Sea. Deep Sea Res II 42:1225-1252

Capone DG (2000) The marine nitrogen cycle. In: Kirchman DL (ed) Microbial ecology of the oceans. Wiley-Liss, New York, p 455-493

> Cho BC, Azam F (1995) Urea decomposition by bacteria in the Southern California Bight and its implications for the mesopelagic nitrogen cycle. Mar Ecol Prog Ser 122:21-26

Cho BC, Park MG, Shim JH, Azam F (1996) Significance of bacteria in urea dynamics in coastal surface waters. Mar Ecol Prog Ser 142:19-26

Cimbleris ACP, Cáceres O (1991) Kinetics of urea uptake by Melosira italica (Ehr.) Kütz at different luminosity conditions. Hydrobiologia 220:211-216

> Cochlan WP, Herndon J, Kudela RM (2008) Inorganic and organic nitrogen uptake by the toxigenic diatom Pseudonitzschia australis (Bacillariophyceae). Harmful Algae 8: 111-118

> Collier JL, Brahamsha B, Palenik B (1999) The marine cyanobacterium Synechococcus sp. WH7805 requires ure- ase (urea amidohydrolase, EC 3.5.1.5) to utilize urea as a nitrogen source: molecular-genetic and biochemical analysis of the enzyme. Microbiology 145:447-459

Collier JL, Baker KM, Bell SL (2009) Diversity of urea-degrading microorganisms in open-ocean and estuarine planktonic communities. Environ Microbiol 11: 3118-3131

Collos Y, Gagne C, Laabir M, Vaquer A, Cecchi P, Souchu P (2004) Nitrogenous nutrition of Alexandrium catenella (Dinophyceae) in cultures and in Thau lagoon, southern France. J Phycol 40:96-103

> Cornell S, Rendell A, Jickells T (1995) Atmospheric inputs of dissolved organic nitrogen to the oceans. Nature 376 : 243-246

> Corner EDS, Newell BS (1967) On nutrition and metabolism of zooplankton 4 . Forms of nitrogen excreted by Calanus. J Mar Biol Assoc UK 47:113-120

Cunningham TS, Cooper TG (1991) Expression of the DAL80 gene, whose product is homologous to the GATA factors and is a negative regulator of multiple nitrogen catabolic genes in Saccharomyces cerevisiae, is sensitive to nitrogen catabolite repression. Mol Cell Biol 11:6205-6215

Cunningham TS, Andhare R, Cooper TG (2000) Nitrogen catabolite repression of DAL80 expression depends on the relative levels of Gat1p and Ure2p production in Saccharomyces cerevisiae. J Biol Chem 275:14408-14414

Dugdale RC, Goering JJ (1967) Uptake of new and regenerated forms of nitrogen in primary productivity. Limnol Oceanogr 12:196-206

Dyhrman ST, Anderson DM (2003) Urease activity in cultures and field populations of the toxic dinoflagellate Alexandrium. Limnol Oceanogr 48:647-655

Egleston ES, Morel FMM (2008) Nickel limitation and zinc toxicity in a urea-grown diatom. Limnol Oceanogr 53:2462-2471

Espinosa J, Forchammer K, Burillo S, Conteras A (2006) Interaction network in cyanobacterial nitrogen regulation: PipX, a protein that interacts in a 2-oxoglutarate dependent manner with PII and NctA. Mol Microbiol 61:457-469

> Fan C, Glibert PM (2005) Effects of light on nitrogen and carbon uptake during a Prorocentrum minimum bloom. Harmful Algae 4:629-642

Fan C, Glibert PM, Alexander J, Lomas MW (2003a) Characterization of urease activity in three marine phytoplankton species, Aureococcus anophagefferens, Prorocentrum minimum, and Thalassiosira weissflogii. Mar Biol 142: 949-958

Fan CL, Glibert PM, Burkholder JM (2003b) Characterization of the affinity for nitrogen, uptake kinetics, and environmental relationships for Prorocentrum minimum in natural blooms and laboratory cultures. Harmful Algae 2:283-299

Ferguson RL, Collier A, Meeter DA (1976) Growth response of Thalassiosira pseudonana Hasle and Heimdal clone $3 \mathrm{H}$ to illumination, temperature and nitrogen source. Chesapeake Sci 17:148-158

> Flores E, Frías JE, Rubio LM, Herrero A (2005) Photosynthetic nitrate assimilation in cyanobacteria. Photosynth Res 83:117-133

Garrett RH, Grisham CM (1995) Biochemistry. Harcourt Brace, Orlando, FL

Genbauffe FS, Cooper TG (1986) Induction and repression of the urea amidolyase gene in Saccharomyces cerevisiae. Mol Cell Biol 6:3954-3964

Georis I, Feller A, Vierendeels F, Dubois E (2009) The yeast GATA factor Gat1 occupies a central position in nitrogen catabolite repression-sensitive gene activation. Mol Cell Biol 29:3803-3815

Glibert PM, Terlizzi DE (1999) Cooccurrence of elevated urea 
levels and dinoflagellate blooms in temperate estuarine aquaculture ponds. Appl Environ Microbiol 65:5594-5596

Glibert PM, Garside C, Fuhrman JA, Roman MR (1991) Time dependent coupling of inorganic and organic nitrogen uptake and regeneration in the plume of the Chesapeake Bay estuary and its regulation by large heterotrophs. Limnol Oceanogr 36:895-909

Glibert PM, Magnien R, Lomas MW, Alexander J and others (2001) Harmful algal blooms in the Chesapeake and coastal bays of Maryland, USA: comparison of 1997, 1998, and 1999 events. Estuaries 24:875-883

Glibert PM, Trice TM, Michael B, Lane L (2005) Urea in the tributaries of the Chesapeake and coastal bays of Maryland. Water Air Soil Pollut 160:229-243

Glibert PM, Harrison J, Heil C, Seitzinger S (2006) Escalating worldwide use of urea - a global change contributing to coastal eutrophication. Biogeochemistry 77:441-463

Glibert PM, Azanza R, Burford M, Furuya K and others (2008) Ocean urea fertilization for carbon credits poses high ecological risks. Mar Pollut Bull 56:1049-1056

Gobler CJ, Renaghan MJ, Buck NJ (2002) Impacts of nutrients and grazing mortality on the abundance of Aureococcus anophagefferens during a New York brown tide bloom. Limnol Oceanogr 47:129-141

> Hansell DA, Goering JJ (1989) A method for estimating uptake and production rates for urea in seawater using $\left[{ }^{14} \mathrm{C}\right]$ urea and $\left[{ }^{15} \mathrm{~N}\right]$ urea. Can J Fish Aquat Sci 46:198-202

Harrison WG, Head EJH, Conover RJ, Longhurst AR, Sameoto DD (1985) The distribution and metabolism of urea in the eastern Canadian Arctic. Deep-Sea Res Part A 32: $23-42$

> Hausinger RP (2004) Metabolic versatility of prokaryotes for urea decomposition. J Bacteriol 186:2520-2522

> Healey FP (1977) Ammonium and urea uptake by some freshwater algae. Can J Bot 55:61-69

> Herndon J, Cochlan WP (2007) Nitrogen utilization by the raphidophyte Heterosigma akashiwo: growth and uptake kinetics in laboratory cultures. Harmful Algae 6:260-270

> Hildebrand M, Dahlin K (2000) Nitrate transporter genes from the diatom Cylindrotheca fusiformis (Bacillariophyceae): mRNA levels controlled by nitrogen source and by the cell cycle. J Phycol 36:702-713

Holmes RM, Aminot A, Kerouel R, Hooker BA, Peterson BJ (1999) A simple and precise method for measuring ammonium in marine and freshwater systems. Can J Fish Aquat Sci 56:1801-1808

- Howard MDA, Cochlan WP, Ladizinsky N, Kudela RM (2007) Nitrogenous preference of toxigenic Pseudo-nitzschia australis (Bacillariophyceae) from field and laboratory experiments. Harmful Algae 6:206-217

Jahns T (1992a) Regulation of urea uptake in Pseudomonas aeruginosa. Antonie Leeuwenhoek 62:173-179

Jahns T (1992b) Urea uptake by the marine bacterium Deleya venusta HG1. J Gen Microbiol 138:1815-1820

Jahns T, Kaltwasser H (1989) Energy-dependent uptake of urea by Bacillus megaterium. FEMS Microbiol Lett 57: 13-18

> Jahns T, Zobel A, Kleiner D, Kaltwasser H (1988) Evidence for carrier-mediated, energy-dependent uptake of urea in some bacteria. Arch Microbiol 149:377-383

Jauzein C, Collos Y, Garces E, Vila M, Maso M (2008a) Shortterm temporal variability of ammonium and urea uptake by Alexandrium catenella (Dinophyta) in cultures. J Phycol 44:1136-1145

> Jauzein C, Loureiro S, Garces E, Collos Y (2008b) Interactions between ammonium and urea uptake by five strains of Alexandrium catenella (Dinophyceae) in culture. Aquat Microb Ecol 53:271-280
Jørgensen NOG (2006) Uptake of urea by estuarine bacteria. Aquat Microb Ecol 42:227-242

Jørgensen NOG, Kroer N, Coffin RB, Hoch MP (1999a) Relations between bacterial nitrogen metabolism and growth efficiency in an estuarine and an open-water ecosystem. Aquat Microb Ecol 18:247-261

> Jørgensen NOG, Tranvik LJ, Berg GM (1999b) Occurrence and bacterial cycling of dissolved nitrogen in the Gulf of Riga, the Baltic Sea. Mar Ecol Prog Ser 191:1-18

Jung H (2002) The sodium/substrate symporter family: structural and functional features. FEBS Lett 529:73-77

Kanamori T, Kanou N, Atomi H, Imanaka T (2004) Enzymatic characterization of a prokaryotic urea carboxylase. J Bacteriol 186:2532-2539

Kaufman ZG, Lively JS, Carpenter EJ (1983) Uptake of nitrogenous nutrients by phytoplankton in a barrier island estuary: Great South Bay, New York. Estuar Coast Shelf Sci 17:483-493

Kirchman DL, Suzuki Y, Garside C, Ducklow HW (1991) High turnover rates of dissolved organic carbon during a spring phytoplankton bloom. Nature 352:612-614

> Kirk DL, Kirk MM (1978) Amino acid and urea uptake in 10 species of Chlorophyta. J Phycol 14:198-203

Koper TE, El-Sheikh AF, Norton JM, Klotz MG (2004) Ureaseencoding genes in ammonia-oxidizing bacteria. Appl Environ Microbiol 70:2342-2348

- Kramer JG, Morris I (1990) Growth regulation in irradiance limited marine Synechococcus sp. WH 7803. Arch Microbiol 154:286-293

Kristiansen S (1983) Urea as a nitrogen source for the phytoplankton in the Oslofjord. Mar Biol 74:17-24

Kudela RM, Cochlan WP (2000) Nitrogen and carbon uptake kinetics and the influence of irradiance for a red tide bloom off southern California. Aquat Microb Ecol 21: 31-47

> Kudela RM, Lane JQ, Cochlan WP (2008) The potential role of anthropogenically derived nitrogen in the growth of harmful algae in California, USA. Harmful Algae 8: $103-110$

> L'Helguen S, Slawyk G, Le Corre P (2005) Seasonal patterns of urea regeneration by size-fractionated microheterotrophs in well-mixed temperate coastal waters. J Plankton Res 27:263-270

Leftley JW, Syrett PJ (1973) Urease and ATP: urea amidolyase activity in unicellular algae. J Gen Microbiol 77:109-115

- Levasseur M, Thompson PA, Harrison PJ (1993) Physiological acclimation of marine phytoplankton to different nitrogen sources. J Phycol 29:587-595

Lindell D, Post AF (2001) Ecological aspects of ntcA gene expression and its use as an indicator of the nitrogen status of marine Synechococcus spp. Appl Environ Microbiol 67:3340-3349

Lomas MW (2004) Nitrate reductase and urease enzyme activity in the marine diatom Thalassiosira weissflogii (Bacillariophyceae): interactions among nitrogen substrates. Mar Biol 144:37-44

Lomas MW, Glibert PM (1999) Temperature regulation of nitrate uptake: a novel hypothesis about nitrate uptake and reduction in cool-water diatoms. Limnol Oceanogr 44:556-572

> Lomas MW, Glibert PM, Berg GM, Burford M (1996) Characterization of nitrogen uptake by natural populations of Aureococcus anophagefferens (Chrysophyceae) as a function of incubation duration, substrate concentration, light, and temperature. J Phycol 32:907-916

> Lomas MW, Trice TM, Glibert PM, Bronk DA, McCarthy JJ (2002) Temporal and spatial dynamics of urea uptake and 
regeneration rates and concentrations in Chesapeake Bay. Estuaries 25:469-482

Lomstein BA, Blackburn TH, Henriksen K (1989) Aspects of nitrogen and carbon cycling in the northern Bering Shelf sediment. I. The significance of urea turnover in the mineralization of $\mathrm{NH}_{4}^{+}$. Mar Ecol Prog Ser 57:237-247

Lund BA (1987) Mutual interference of ammonium, nitrate, and urea on uptake of ${ }^{15} \mathrm{~N}$ sources by the marine diatom Skeletonema costatum (Grev) cleve. J Exp Mar Biol Ecol 113:167-180

Lund BA, Blackburn TH (1989) Urea turnover in coastal marine sediment measured by a ${ }^{14} \mathrm{C}$-urea short-term incubation. J Microbiol Methods 9:297-308

> Mace KA, Kubilay N, Duce RA (2003) Organic nitrogen in rain and aerosol in the eastern Mediterranean atmosphere: an association with atmospheric dust. J Geophys Res 108(D10), 4320, doi:10.1029/2002JD002997

Mariscal V, Moulin P, Orsel M, Miller AJ, Fernandez E, Galvan A (2006) Differential regulation of the Chlamydamonas Nar1 gene family by carbon and nitrogen. Protist 157:421-433

Mayzaud P (1973) Respiration et excrétion azotée du zooplankton. III. Etude de l'influence des variations thermiques. Ann Inst Oceanogr 49:113-122

McCarthy JJ (1970) A urease method for urea in seawater. Limnol Oceanogr 15:309-313

McCarthy JJ (1972) Uptake of urea by natural populations of marine phytoplankton. Limnol Oceanogr 17:738-748

McCarthy JJ, Kamykowski D (1972) Urea and other nitrogenous nutrients in La Jolla Bay during February, March, and April 1970. Fish Bull 70:1261-1274

McCarthy JJ, Whitledge T (1972) Nitrogen excretion by anchovy (Engraulis mordax and E. ringens) and jack mackerel (Trachurus symmetricus). Fish Bull 70:395-401

McIninch JK, McIninch JD, May SW (2003) Catalysis, stereochemistry, and inhibition of ureidoglycolate lyase. J Biol Chem 278:50091-50100

Menden-Deuer S, Lessard EJ (2000) Carbon to volume relationships for dinoflagellates, diatoms and other protist plankton. Limnol Oceanogr 45:569-579

Middelburg JJ, Nieuwenhuize J (2000) Nitrogen uptake by heterotrophic bacteria and phytoplankton in the nitraterich Thames estuary. Mar Ecol Prog Ser 203:13-21

Miller CA, Glibert PM (1998) Nitrogen excretion by the calanoid copepod Acartia tonsa: results of mesocosm experiments. J Plankton Res 20:1767-1780

Miller CA, Roman MR (2008) Effects of food nitrogen content and concentration on the forms of nitrogen excreted by the calanoid copepod, Acartia tonsa. J Exp Mar Biol Ecol 359:11-17

Mitamura O, Saijo Y (1981) Studies on the seasonal changes of dissolved organic carbon, nitrogen, phosphorus and urea concentrations in Lake Biwa. Arch Hydrobiol 91: $1-14$

Mobley HLT, Hausinger RP (1989) Microbial ureases: significance, regulation, and molecular characterization. Microbiol Rev 53:85-108

Mobley HLT, Island MD, Hausinger RP (1995) Molecular biology of microbial ureases. Microbiol Rev 59:451-480

Molloy CJ, Syrett PJ (1988) Interrelationships between uptake of urea and uptake of ammonium by microalgae. J Exp Mar Biol Ecol 118:85-95

Muhlstein HI, Villareal TA (2007) Organic and inorganic nutrient effects on growth rate-irradiance relationships in the Texas brown-tide alga Aureoumbra lagunensis (Pelagophyceae). J Phycol 43:1223-1226

Muro-Pastor MI, Reyes JC, Florencio FJ (2005) Ammonium assimilation in cyanobacteria. Photosynth Res 83:135-150

Neilson AH, Larsson T (1980) The utilization of organic nitrogen for growth of algae-physiological aspects. Physiol Plant 48:542-553

> Oliveira L, Antia NJ (1986) Some observations on the ureadegrading enzyme of the diatom Cyclotella cryptica and the role of nickel in its production. J Plankton Res 8: $235-242$

Painter SC, Sanders R, Waldron HN, Lucas MI, Torres-Valdes S (2008) Urea distribution and uptake in the Atlantic Ocean between 50 degrees $\mathrm{N}$ and 50 degrees S. Mar Ecol Prog Ser 368:53-63

> Palinska KA, Jahns T, Rippka R, Tandeau De Marsac N (2000) Prochlorococcus marinus strain PCC 9511, a picoplanktonic cyanobacterium, synthesizes the smallest urease. Microbiology 146:3099-3107

Parker MS, Armbrust EV (2005) Synergistic effects of light, temperature, and nitrogen source on transcription of genes for carbon and nitrogen metabolism in the centric diatom Thalassiosira pseudonana (Bacillariophyceae). J Phycol 41:1142-1153

Parker MS, Mock T, Armbrust EV (2008) Genomic insights into marine microalgae. Annu Rev Genet 42:619-645

Pedersen H, Lomstein BA, Blackburn TH (1993) Evidence for bacterial urea production in marine sediments. FEMS Microbiol Ecol 12:51-59

Peers GS, Milligan AJ, Harrison PJ (2000) Assay optimization and regulation of urease activity in two marine diatoms. J Phycol 36:523-528

Peierls BL, Paerl HW (1997) Bioavailability of atmospheric organic nitrogen deposition to coastal phytoplankton. Limnol Oceanogr 42:1819-1823

Pustizzi F, MacIntyre H, Warner ME, Hutchins DA (2004) Interaction of nitrogen source and light intensity on the growth and photosynthesis of the brown tide alga Aureococcus anophagefferens. Harmful Algae 3:343-360

> Quintero MJ, Muro-Pastor AM, Herrero A, Flores E (2000) Arginine catabolism in the cyanobacterium Synechocystis sp. strain PCC 6803 involves the urea cycle and arginase pathway. J Bacteriol 182:1008-1015

Raunser S, Mathai JC, Abeyrathne PD, Rice AJ, Zeidel ML, Walz T (2009) Oligomeric structure and functional characterization of the urea transporter from Actinobacillus pleuropneumoniae. J Mol Biol 387:619-627

Rees TAV, Syrett PJ (1979) Uptake of urea by the diatom, Phaeodactylum. New Phytol 82:169-178

Revilla M, Alexander J, Glibert PM (2005) Urea analysis in coastal waters: comparison of enzymatic and direct methods. Limnol Oceanogr Methods 3:290-299

> Ronquist F, Huelsenbeck JP (2003) MRBAYES 3: Bayesian phylogenetic inference under mixed models. Bioinformatics 19:1572-1574

> Roon RJ, Levenberg B (1972) Urea amidolyase. I. Properties of enzyme from Candida utilis. J Biol Chem 247:4107-4113

Sanderson MP, Bronk DA, Nejstgaard JC, Verity PG, Sazhin AF, Frischer ME (2008) Phytoplankton and bacterial uptake of inorganic and organic nitrogen during an induced bloom of Phaeocystis pouchetii. Aquat Microb Ecol 51:153-168

Shah N, Syrett PJ (1982) Uptake of guanine by the diatom Phaeodactylum tricornutum. J Phycol 18:579-587

- Shah N, Syrett PJ (1984) The uptake of guanine and hypoxanthine by marine microalgae. J Mar Biol Assoc UK 64: $545-556$

Siewe RM, Weil B, Burkovski A, Eggeling L, Kramer R, Jahns $\mathrm{T}$ (1998) Urea uptake and urease activity in Corynebacterium glutamicum. Arch Microbiol 169:411-416 
Silberbach M, Burkovski A (2006) Application of global analysis techniques to Corynebacterium glutamicum: new insights into nitrogen regulation. J Biotechnol 126:101-110

Sinclair G, Kamykowsi D, Glibert PM (2009) Growth, uptake, and assimilation of ammonium, nitrate, and urea by three strains of Karenia brevis grown under low light. Harmful Algae 8:770-780

Siuda W, Chróst RJ (2006) Urea and ureolytic activity in lakes of different trophic status. Pol J Microbiol 55:211-225

Smil V (2001) Enriching the Earth: Fritz Haber, Carl Bosch, and the transformation of world food production. MIT Press, Cambridge, MA

Solomon CM (2006) Regulation of estuarine phytoplankton and bacterial urea uptake and urease activity by environmental factors. PhD dissertation, University of Maryland, College Park, MD

Solomon CM, Glibert PM (2008) Urease activity in five phytoplankton species. Aquat Microb Ecol 52:149-157

Solomon CM, Alexander JA, Glibert PM (2007) Measuring urease activity in aquatic environmental samples. Limnol Oceanogr Methods 5:280-288

Strom SL, Bright KJ (2009) Inter-strain differences in nitrogen use by the coccolithophore Emiliania huxleyi, and consequences for predation by a planktonic ciliate. Harmful Algae 8:811-816

Su Z, Olman V, Mao F, Xu Y (2005) Comparative genomics analysis of NtcA regulons in cyanobacteria: regulation of nitrogen assimilation and its coupling to photosynthesis. Nucleic Acids Res 33:5156-5171

Switzer T (2008) Urea loading from a spring storm-Knysna estuary, South Africa. Harmful Algae 8:66-69

Tam LT, Eymann C, Antelmann H, Albrecht D, Hecker M (2007) Global gene expression profiling of Bacillus subtilis in response to ammonium and tryptophan starvation as revealed by transcriptome and proteome analysis. J Mol Microbiol Biotechnol 12:121-130

Tamminen T, Irmisch A (1996) Urea uptake kinetics of a midsummer planktonic community on the SW coast of Finland. Mar Ecol Prog Ser 130:201-211

Therkildsen MS, Isaksen MF, Lomstein BA (1997) Urea production by the marine bacteria Delaya venusta and Pseudomonas stutzeri grown in a minimal medium. Aquat Microb Ecol 13:213-217

Thessen AE, Bowers HA, Stoecker DK (2009) Intra- and interspecific differences in Pseudo-nitzschia growth and toxi-

Editorial responsibility: Gerhard Herndl,

Vienna, Austria city while utilizing different nitrogen sources. Harmful Algae 8:792-810

Thompson JD, Higgins DG, Gibson TJ (1994) CLUSTAL-W: improving the sensitivity of progressive multiple sequence alignment through sequence weighting, position-specific gap penalities and weight matrix choice. Nucleic Acids Res 22:4673-4680

Timperley MH, Vigorbrown RJ, Kawashima M, Ishigami M (1985) Organic nitrogen compounds in atmospheric precipitation-their chemistry and availability to phytoplankton. Can J Fish Aquat Sci 42:1171-1177

Tolonen AC, Aach J, Lindell D, Johnson ZI and others (2006) Global gene expression of Prochlorococcus ecotypes in response to changes in nitrogen availability. Mol Syst Biol $2: 53$

> Twomey LJ, Piehler MF, Paerl HW (2005) Phytoplankton uptake of ammonium, nitrate and urea in the Neuse River Estuary, NC, USA. Hydrobiologia 533:123-134

Valladares A, Montesinos ML, Herrero A, Flores E (2002) An $\mathrm{ABC}$-type, high-affinity urea permease identified in cyanobacteria. Mol Microbiol 43:703-715

Vardi A, Thamatrakoln K, Bidle KD, Falkowski PG (2008) Diatom genomes come of age. Genome Biol 9:245

Vogels GD, Van der Drift C (1976) Degradation of purines and pyrimidines by microorganisms. Microbiol Mol Biol Rev 40:403-468

Waldron HN, Attwood CG, Probyn TA, Lucas MI (1995) Nitrogen dynamics in the Bellinghausen Sea during the austral spring of 1992. Deep Sea Res II 42:1253-1276

- Wang WH, Kohler B, Cao FQ, Liu LH (2008) Molecular and physiological aspects of urea transport in higher plants. Plant Sci 175:467-477

Wheeler PA (1983) Phytoplankton nitrogen metabolism. In: Carpenter EJ, Capone DG (eds) Nitrogen in the marine environment. Academic Press, New York, p 309-346

Wheeler PA, Kirchman DL (1986) Utilization of inorganic and organic nitrogen by bacteria in marine systems. Limnol Oceanogr 31:998-1009

Zehr JP, Ward BB (2002) Nitrogen cycling in the ocean: new perspectives on processes and paradigms. Appl Environ Microbiol 68:1015-1024

Zubkov MV, Tarran GA (2005) Amino acid uptake of Prochlorococcus spp. in surface waters across the South Atlantic Subtropical Front. Aquat Microb Ecol 40: $241-249$

Submitted: July 3, 2009; Accepted: November 16, 2009

Proofs received from author(s): March 12, 2010 